\title{
İskelet displazilerinde genel değerlendirme
}

\section{Overall evaluation of skeletal dysplasias}

\author{
Pelin Özlem Şimşek Kiper ${ }^{1}$, Yasemin Alanay²
}

\begin{abstract}
${ }^{1}$ Hacettepe Üniversitesi Tıp Fakültesi Çocuk Sağlığı ve Hastalıkları Anabilim Dalı, Pediatrik Genetik Bilim Dalı, Ankara, Türkiye ${ }^{2}$ Acıbadem Üniversitesi Tıp Fakültesi Çocuk Sağlığı ve Hastalıkları Anabilim Dalı, Pediatrik Genetik Bilim Dalı, İstanbul, Türkiye
\end{abstract}

\begin{abstract}
İskeletin genetik hastalıkları klinik ve genetik etiyoloji açısından heterojen bir grup hastalıktır. Bu grup içinde yer alan ve önemli bir yere sahip olan osteokondrodisplaziler (iskelet displazileri) genellikle yapısal proteinler, metabolik yolaklar ve büyüme plağındaki regülasyon bozukluklarından kaynaklanan kemik ve/veya kıkırdağın gelişim ve büyümesinin etkilendiği doğuştan iskelet hastalıklarıdır. İskelet displazilerinde esas olarak kemik ve kıkırdak dokular etkilense de kas, tendon ve bağlar da ciddi derecede etkilenebilir. Tek tek ele alındıklarında nadir hastalıklar olarak değerlendirilen iskelet displazilerinin grup olarak insidansı yaklaşık 1/5000 olarak bildirilmiştir. Bununla birlikte, ülkemiz gibi akraba evliliği oranının yüksek olduğu ülkelerde iskelet displazisi görülme sıklığının literatürde bildirilenden çok daha yüksek olduğu tahmin edilmektedir. "International Skeletal Dysplasia Society" tarafından 2015 yılında yayımlanan nozoloji ve sınıflamaya göre iskeletin genetik hastalıkları, klinik, radyolojik ve moleküler kriterlere göre 42 grup altında incelenen 364 gen defektinden en az birinin etken olarak gösterildiği 436 antiteden oluşmaktadır. Bu derlemede, iskelet sistemi ile ilgili temel bazı kavramların gözden geçirilmesi ve orantısız boy kısalığı tespitinden iskelet displazisi şüphesi ve tanısına kadar uzanan sürecin sistematik bir şekilde ele alınması hedeflenmiştir.
\end{abstract}

Anahtar sözcülkler: iskelet displazisi; orantısız boy kısalığı
The genetic disorders of the skeleton are a genetically and clinically heterogeneous group of disorders. Within this group, osteochondrodysplasias (skeletal dysplasias) have an important place, and generally arise from the defects in structural proteins, metabolic processes, or growth plate regulation and affect the development and growth of cartilage and/or bone. Cartilage and bone are the primary sites of involvement in skeletal dysplasias, however, muscle, tendon and ligaments may also be affected. Although each skeletal dysplasia is relatively rare, collectively the birth incidence of these disorders is almost $1 / 5000$. However, in countries with a high consanguineous marriage rate, such as Turkey, the prevalence of skeletal dysplasia might be higher than the prevalence reported in the literature. In the 2015 revision of the Nosology and Classification of Genetic Skeletal Disorders of "International Skeletal Dysplasia Society" there are 436 entities classified under 42 groups primarily on the basis of clinical, radiographic, and molecular criteria with mutations in one or more of 364 genes. In this review, basic knowledge about the skeleton system will be reviewed and a systematic approach to a patient with suspected skeletal dysplasia will be described.

Key words: skeletal dysplasias; disproportionate short stature

kemiklerde eğrilik, brakidaktili, polidaktili, oligodaktili, asimetri gibi) veya tekrarlayıcı eklem dislokasyonu gibi farklı kas-iskelet sistemi bulguları ile başvurabilirler. Bunun yanısıra hastalarda; dismorfik yüz bulguları, konjenital kalp defekti, konjenital megakolon, renal anomaliler ve göz bulguları gibi diğer sistemleri ilgilendiren bulgular da saptanabilir. Doğru tanının zamanında koyulması bu hastalıklara eşlik edebilecek çeşitli morbiditelerin önlenmesinde ve tekrar eden gebelik kayıpları yaşayan ailelere yol gösterilmesinde önemli katkılar sağlamaktadır.

- İletişim adresi: Doç. Dr. Pelin Özlem Şimşek Kiper, Hacettepe Üniversitesi Tıp Fakültesi Çocuk Sağlığı ve Hastalıkları Anabilim Dalı, Pediatrik Genetik Bilim Dalı, Ankara, Türkiye Tel: 0312 - 3115522 e-posta: pelinozlem@hacettepe.edu.tr

- Geliş tarihi: 8 Ağustos $2016 \quad$ Kabul tarihi: 8 Ağustos 2016 


\section{ISKELET SISTEMI EMBRIYOLOJisi}

İnsan iskeleti 206 kemikten (126 appendiküler kemik, 74 aksiyel kemik ve altı kemikçik) oluşan karmaşık bir organdır. Kas-iskelet sistemi; tendon, bağ, kas, kıkırdak ve kemikten oluşur ve lineer büyüme, hareket sırasında mekanik destek, kan ve mineral depolama ve hayati organların korunması gibi fonksiyonları vardır. İskelet sistemi embriyolojik köken olarak mezoderm ve nöral krest orijinli mezenkim hücrelerinden meydana gelir. Paraksiyel mezoderm nöral tüpün her iki yanında somitomer ve somit adı verilen yapıları oluşturur. Somitler daha sonra ventral bölgede sklerotom ve dorsolateral bölgede dermomiyotom oluşturacak şekilde farklılaşır. Gestasyonel dördüncü haftanın sonunda sklerotom hücreleri polimorf hale gelir, gevşek bir doku olan mezenkim veya embriyonik bağ dokuyu meydana getirir. Mezenkimal hücreler göç ederek çok farklı yollarla farklı hücrelere dönüşebilir. Fibroblast, kondroblast veya osteoblastlar bu şekilde oluşur. Vücut duvarının somatik mezodermindeki hücreler pelvis, omuz bölgesi kemikleri ve ekstremitelerin uzun kemiklerinin oluşumunda etkilidir. Kraniyal bölgedeki nöral krest hücreleri doğrudan mezenkime dönüşerek yüz ve kafatası kemiklerinin oluşumuna katkıda bulunur. Vertebraların gelişimi anne karnındaki dördüncü haftada başlar. Sklerotom hücreleri spinal kord ve notokordu çevreler. Sklerotom blokları daha az yoğun olan bölgelerle birbirinden ayrılacak ve bu az yoğun bölgelere intersegmental arterler yerleşecektir. Bir sklerotomun kaudal ve sefalik bölgeleri arasındaki bölge, intervertebral disk oluşumuna zemin hazırlayacaktır. Kostalar torasik vertebraların kostal uzantıları tarafindan oluşturulur, paraksiyel mezodermin sklerotom kısımlarından gelişir. Sternum ise tamamen bağımsız olarak ventral vücut duvarındaki somatik mezodermden oluşur. İskeletin şekil alması, fetal gelişim sırasında meydana gelir. Mezenkim gelecekte kemik dokusuna dönüşecek bölgelerde endokondral ve intramembranöz ossifikasyon olmak üzere iki farklı mekanizma aracilığıyla hücresel kondansasyona uğrar. Endokondral ossifikasyonda mezenkimal hücreler, öncelikle hiyalin kıkırdak modelleri (kıkırdak anlagen) oluşturur. Ardından bu kıkırdak modelin orta kısımları yıkıma uğrar, mineralize olur ve osteoklast benzeri hücreler tarafından ortadan kaldırılır. Bu işlem, kemiğin üst ve alt kısımlarına yayılarak devam eder. $\mathrm{Bu}$ gelişmeleri vasküler yapıların invazyonu ve kemik öncülü hücrelerin ortama gelmesi izler; şaftın ortasındaki periost osteoblast hücrelerini üretir ve bunlar da korteksi sentezler. Yeni oluşan yapının tümüne primer ossifikasyon merkezi denir. Kıkırdak modellerin uçlarında da benzer bir işlem devam eder. Kıkırdak yıkılarak sekonder ossifikasyon merkezleri oluşur. Kemiğin şaft kısmındaki primer merkezden uçlardaki kıkırdak modellere doğru ossifikasyon ilerler. On ikinci haftanın sonunda, ossifikasyon merkezleri arasındaki kıkırdak "büyüme plağı" veya "epifız" adı verilen bir alanda sıkışıp kalır. Epifizyel büyüme plakları adı verilen bu kondrosit adacıkları oldukça organize yapılardır. Uzun kemiklerin uzamasında bu plağın büyük önemi vardır. Plağın her iki tarafında da endokondral ossifikasyon devam eder. Büyüme tamamlandığında bu plak kaybolacak ve kemiğin şaftı ile birleşecektir. Doğumda; diyafizler genellikle tamamen kemikleşmiştir, ancak epifizlerin çoğu halen kıkırdak yapıdadır. Bir yenidoğan radyografisinde, yalnızca proksimal tibial ve distal femoral epifizler görülebilir. Büyüme plağındaki kondrositler, proliferasyon, hipertrofi, yıkılma ve kemik doku ile yer değiştirme süreçlerinden oluşan ve bilinen veya henüz bilinmeyen pek çok gen tarafindan sıkı bir kontrol altında tutulan bir programdan geçer. Endokondral kemik oluşumunda prolifere olan kondrositler, büyüme plağında paralel kolonlar oluşturarak kollajen Tip II, IX, XI ve aggrecan gibi proteoglikanları eksprese eder. Kondrositler farklılaşınca hipertrofik olur ve yüksek düzeyde alkalen fosfotaz ve kollajen Tip X üretir. Terminal şekilde farklılaşan kondrositler apoptozise uğrar. Kıkırdak matriks mineralize olur ve kemik dokusu ile yer değiştirir. Bazı transkripsiyon faktörleri (SOX9, Runx2, Runx3), büyüme faktörleri (fibroblast büyüme faktörleri, Wnts, vasküler endotelyal büyüme faktörü (VEGF), kemik morfojenik proteinleri (BMP), TGF-beta, insülin benzeri büyüme faktörleri ve tiroid hormonları, ekstrasellüler matriks proteinleri (kollajen, proteoglikanlar, matriks metalloproteinazları) ve epigenetik faktörler (histon deasetilazlar, DNA metilasyonu) bütün bu süreçlerde önemli rol oynar. ${ }^{[4]}$ Kraniyumun yassı kemikleri, klavikulanın bazı kısımları ve pubik kemik mezenkimal hücrelerden köken alan fibröz dokunun doğrudan kemik üzerine yayılan osteoblastlara dönüştüğü intramembranöz ossifikasyon ile meydana gelir. İskeletogenezin esas mekanizması olarak bilinen bu mekanizmalar sonucunda, kemik boyunda uzama ve eklem yüzey çaplarında artış meydana gelir; bu yolakları kodlayan genlerde ve büyüme plağındaki bozukluklar iskelet displazilerine neden olur. ${ }^{[5]} \mathrm{Bu}$ nedenle, büyüme plağını ve fonksiyonlarını iyi bilmek, bu hastalık grubunun moleküler patofizyolojisini anlamakta çok önemlidir.

\section{KIKIRDAK YAPI}

Büyüme plağı kondrositleri koordineli bir farklılaşma süreci yaşar. Plağın epifizyel tarafındaki kondrositler prolifere olur, büyür ve farklılaşır. Kollajen Tip $X$ ekspresyonu ve hücre ölümleri farklılaşmanın son basamaklarıdır. Bu işlemde birçok hücre sinyal yolağı 
ve matriks molekülleri rol oynar. Kondrositler ekstrasellüler matriksi oluşturacak birçok protein sentezler. Kollajenler bunların en önemlilerindendir. Kollajenler, üçlü heliks yapı oluşturmak üzere üç polipeptid zincirin bir araya geldiği, tekli moleküllerden (monomerler) oluşan bir protein ailesidir. Üçlü heliksteki her üçüncü aminoasid bir glisin rezidüsü olup, genel olarak zincir yapısı Gly-X-Y olarak gösterilir. X ve Y sıklıkla sırasıyla proline ve hidroksiprolindir. Kollajenin üçlü heliks yapısı kollajen tiplerine göre değişiklik gösterir. Kollajen heliksi, kollajen Tip II'de olduğu gibi birbirinin aynı zincirlerden (homotrimerik) oluşabilir ya da Tip I, IX, XI kollajende olduğu gibi birbirinden farklı kollajen zincirlerden (heterotrimerik) meydana gelebilir. ${ }^{[6]}$ Vücudumuzda yaygın bir şekilde bulunan kollajenler, dokulara özgü bir şekilde 33 farklı gen tarafindan eksprese edilir ve bunun sonucunda 19 farklı üçlü heliks kollajen yapısı oluşturulur. En yaygın şekilde bulunan kollajen tipi "fibrillar" tip kollajendir (Tip I, II, III, V, $\mathrm{XI}$ ). Bu tip kollajenler, içerdikleri yoğun çapraz bağlar sayesinde, bulundukları dokuya güç ve dayanıklılık kazandırır; yoğun strese maruz kalan kemik, kıkırdak ve deri gibi bölgelerde bulunur. ${ }^{[7]}$ Bir diğer çeşit kollajen ise "fibril-ilişkili" olandır. Tip IX, XII, XIV ve XVI kollajen bu grup içinde yer alır. Bu tip kollajenler, fibrillar kollajenlerle ve aggrecan, kıkırdak oligomerik protein (COMP), dekorin, fibulin ve diğer sülfatlanmış proteoglikanlardan oluşan ekstrasellüler matriks molekülleriyle etkileşime girer. Kollajen Tip VIII ve $X$ ise fibrillar değildir, kısa zincirli kollajenler olarak bilinir. Kollajen Tip X, endokondrol ossifikasyon sırasında hipertrofik kondrositler tarafından en yaygın şekilde üretilen ekstrasellüler matriks molekülüdür. Eklem kıkırdağında bulunan esas kollajenler, fibrillar kollajen Tip II, IX, X, XI'dir. Gelişmekte olan kıkırdakta esas fibrillar kollajen ağı, kollajen Tip II, IX, XI'un çapraz bağlanmış kopolimerlerini oluşturur. ${ }^{7]}$ Kollajenlerin bu önemli rolleri nedeni ile onları kodlayan genlerdeki mutasyonlar iskelet displazilerine yol açabilmektedir. Kıkırdak dokuda kıkırdağın dayanıklılığında önemli role sahip birçok matriks bileşeni bulunur. Bu moleküller, artiküler kıkırdağın kayganlığına da yardımcı olur. Kollajen Tip II, ekstrasellüler matriksin esas kollajenidir. Kıkırdağın gücünü sağlar, büyüme plağı ve artiküler kıkırdağın temel yapı taşını oluşturur. Kollajen Tip IX ise kollajen Tip II'nin üç boyutlu yapısını oluşturması$\mathrm{n}$ ı sağlar. Matriks proteinlerini üreten genlerdeki bir defekt, iskelet dokunun zamanla yıpranmasına neden olur. Bu tarz defekti olan hastalarda yapılan düzeltici ameliyatlar, yüksek rekürrens hızına sahiptir. Kıkırdak dokunun yapısal proteinleri diğer dokularda da bulunur, bu nedenle iskelet displazilerinde ek fenotipik özellikler de görülebilir. Örneğin kollajen Tip II gözde de bulunduğundan, bu gendeki mutasyonlar gözü de etkiler. Stickler sendromunda yüksek dereceli miyopi görülebilmesi, bu duruma güzel bir örnek oluşturur.

\section{ISKELET SISTEMININ GELIŞiMSEL BOZUKLUKLARI}

İskelet sisteminin gelişimsel bozuklukları; dizostozis, disrüpsiyon, osteolizis ya da displazi şeklinde olabilir.

\section{Dizostozlar}

Defektif kemik gelişimi sonucunda meydana gelen tek bir kemik veya kemik grubunun malformasyonu olarak tanımlanabilir. Erken embriyogenezis sırasında geçici bir süre eksprese edilen bazı transkripsiyon faktörleri ve sinyal moleküllerindeki defektler sonrasında meydana gelir.

\section{Disrüpsiyon}

İskelet dışı nedenlerden meydana gelen kemik malformasyonudur. Geçici bir süre eksprese edilen transkripsiyon faktörleri veya sinyal moleküllerindeki defektlere benzer şekilde bazı toksik maddeler veya enfeksiyöz ajanlar, embriyo üzerinde sınırlı bir süre etki ederek sekonder malformasyonlara neden olabilir. Talidomid ve rubella embriyopatisi veya amniyotik bant sekansı örnek olarak verilebilir.

\section{Osteolizis}

Var olan kemik dokusunun kalıcı regresif bozukluğudur. İskeletin primer gelişimi ve büyümenin ilk fazları normaldir. Bununla beraber, bu fazı ilerleyici kemik rezorbsiyonu ve bazen iskelet ögelerinin kaybolması takip eder. Bazı osteolizis formlarında yaygın bir tutulum bazılarında ise daha sınırı (karpal ve tarsal kemiklerin osteolizisi) bir tutulum görülebilir. Winchester Torg sendromu bu gruba örnek olarak verilebilir. ${ }^{[8]}$

\section{İskelet Displazileri}

Prenatal ve postnatal dönemde ekspresyonu devam eden ve genellikle sinyal yolakları, hücre yapısı ve hücre fonksiyonunu etkileyen gen defektlerinden kaynaklanır. Tek bir kemik veya kemik grubunun malformasyonu olarak tanımlanan dizostozların tersine, displazi genleri organogenez döneminde eksprese olmaz. İskelet displazilerinde, mutasyona uğramış genin ekprese olduğu tüm vücut bölgeleri etkilenebilir. Tutulum genelde simetriktir. Şiddetli boy kısalığı sıktır. Gen ekspresyonu yalnızca belli bölgelerle sınırı olabilir (spinal, rizomelik, mezomelik). Akondroplazi ve Jansen tipi metafizyel displazi bu grubun örnekleridir. Aynı genlerin farklı mutasyonları, hayatın daha ileri evrelerinde eksprese olup hastalıkların daha hafif 
formlarını oluşturabilir. Erken embriyogenezi etkileyen çevresel faktörler dizostozlara, metabolik nedenler daha çok displazilere neden olur. Dizostozlar belirli bir zaman diliminde oluşup gelişimini tamamladığı için, malign dejenerasyon göstermez. Ancak, displaziler postnatal eksprese olan gen defektleri nedeniyle meydana geldikleri için, hücre proliferasyonu ve apoptozis ile ilgili bazı gen defektleri ileride malign transformasyona neden olabilir. Bu duruma örnek olarak, Mafucci sendromu (enkondromatozis) ve fibröz displazi verilebilir. Dizostozis ve iskelet displazilerinin genel özellikleri Tablo 1'de gösterilmiştir. İskelet displazileri ve dizostozların kesişim bölgesinde yer alan bazı hastalıklar da vardır. Bunlara dizostodisplazi adı verilir (Tablo 2). Erken embriyogenezis sırasında eksprese olan ve prenatal ve postnatal yaşamda aktif kalan gen mutasyonları sonucunda meydana gelir. Primer iskelet displazileri kondroosseöz dokuda eksprese olan bazı genlerin mutasyonları ile, sekonder iskelet displazileri ise eksternal faktörlerin kemik ve/veya kıkırdak dokuyu etkilemesi ile oluşur. Hipofosfatemik rikets ve hipotiroidizm bu durumlara örnektir.

\section{ISKELET DISPLAZILERINE KLINIK YAKLAŞIM}

İskelet displazileri iskeletin gelişim, idame ve şeklinde bozukluklara yol açarak, sıklıkla orantısız boy kısalığına neden olur. Bir hekim, iskelet displazisi şüphesi ile prenatal veya postnatal dönemde karşılaşabilir. Klinik yaklaşım, bu iki durum için bazı farklılıklar gösterse de temel olarak benzerdir. İskelet displazisi tanısı prenatal dönemdeki izlemlerde konulduysa, aile öyküsü, klinik ve radyografik bulgular doğrultusunda moleküler testler planlanabilir. Prenatal takipler sırasında bir tanı konulamadıysa veya beklenilmeyen bir durum olarak bir iskelet displazi ile karşı karşıya kalındıysa, sistematik bir yaklaşım sergilemekte her zaman yarar vardır. Yenidoğan bir bebek söz konusu olduğunda, öncelikle bebeğin stabilize edilmesi, hayatı fonksiyonlarının koruma altına alınması ve ardından ayrıntılı bir fizik muayeneden geçirilmesi uygun olacaktır. Bu sırada; bebeğin doğum ağırlığı, doğum boyu, baş çevresi, gögü̉s çevresi, avuç içi ve orta parmak uzunluk ölçümleri mutlaka yapılmalıdır. Bebeğin fizik muayenesi sırasında trakeaya özellikle dikkat edilmelidir. ${ }^{[9]}$ Trakea, 15-20 adet $C$ şeklinde kıkırdak içeren ve hava yolunun sağlanması ve korunması amacıyla yan ve ön kısımları destekleyen trakeal halkalardan oluşur. İskelet displazilerinin çoğunda trakea ile ilgili solunumu, gerekirse entübasyonu ve diğer manipülasyonları zorlaştırabilecek trakeal agenezis, konjenital stenozis, prematür kıkırdak kalsifikasyonları; kısa trakea, trakeomalazi ve trakeoözefageal fistüla gibi anormallikler olabilmektedir. ${ }^{[10]}$ Ölümcül olmayan pek çok iskelet displazisinde, bu patolojiler hastanın prognozunu etkileyebileceğinden, hastaların değerlendirilmeleri sırasında bu noktalara özellikle dikkat edilmelidir.

Prenatal veya postnatal erken dönemde ölümcül olmayan iskelet displazilerinde, bazı istisnaları olmakla beraber, hastalar kliniğe genellikle orantısız boy kısalığı ile başvururlar. Bununla beraber, bazı iskelet displazilerinin klinik olarak orantılı boy kısalığına neden olabileceği de akılda tutulmalıdır (osteogenezis imperfekta ve hipofosfatazya gibi). Boy kısalığı ile başvuran bir hastanın değerlendirilmesinde ilk yapılması gereken, normalin varyantları (ailesel ve yapısal boy kısalığı) ile patolojik durumların ayırt edilmesidir. Ailesel ve yapısal boy kısalıklarının, boy kısalığı nedenlerinin \%75'ini oluşturduğu unutulmamalıdır. Patolojik boy kısalıklarının ise \%10'u kronik hastalıklar, \%6'sı sendromlar, \%5'i kromozom hastalıkları, \%1-2'si büyüme hormonu eksikliği veya reseptör cevapsızlığı, \%1'i ise iskelet displazileri nedeniyle oluşmaktadır. Diğer nadir nedenler arasında, sevgi yoksunluğu ve psikolojik problemler sayılabilir. Patolojik boy kısalıklarında yapılacak bazı antropometrik ölçümler sonrasında hastanın orantıI veya orantısız boy kısalığı olduğunun belirlenmesi, ayırıcı tanı sırasında yardımcı olacaktır. Çok heterojen bir hastalık grubu olması dolayısıyla, iskelet displazisi tanısı koymak güç olabilmektedir. Dikkatli bir öykü, ayrıntılı fizik muayene ve uygun radyolojik değerlendirme, gerekli durumlarda doku örneklemesi ve moleküler analiz ile doğru tanıya gidilebilmektedir.

\section{Öykü}

Hasta ve ailesinden alınacak öykü; prenatal, natal ve postnatal öyküyü ayrıntıları ile içermelidir. Bugün yaklaşık 436 iskelet displazisi arasından 100 kadarının prenatal başlangıçlı olduğu, diğerlerinin ise yenidoğan döneminde veya $2-3$ yaşlarında belirti verdiği bilinmektedir. ${ }^{[11]}$ Doğumda veya ilk birkaç ay içinde tanı konulabilen iskelet displazileri örnekleri Tablo 3'te gösterilmiştir. Aynı aile içinde veya yakın çevrede benzer hastalıkla etkilenmiş başka bireylerin olup olmadığı bilgisi mutlaka sorgulanmalıdır. Prenatal dönemde yapılan ultrasonografi (US) bulguları, doğum boyu ve postnatal dönemde elde edilen büyüme eğrileri tanıya yaklaşımda oldukça önemlidir. Hasta değerlendirmesinde, en az üç nesil içeren ayrıntılı bir soyağacı mutlaka yer almalıdır. İskelet displazileri genetik etiyoloji açısından heterojen bir grup hastalıktır. Etiyolojide; otozomal dominant, otozomal resesif, X'e bağlı resesif, X'e bağlı dominant kalıtım şekilleri ve daha nadiren kromozomal delesyonlar, duplikasyonlar, mozaisizm ve uniparental dizomi görülebilir. ${ }^{[12,13]}$ Aile içinde ve/veya aileler arası değişkenlik söz konusu olabilir. Soyağacı çizimi sırasında bu bilgiler mutlaka göz önünde bulundurulmalıdır. 


\section{Klinik Bulgular}

Klinik bulgular, büyüme ile ilişkili olanlar ve olmayanlar olmak üzere iki grupta incelenebilir.

\section{Büyüme ile ilişkili klinik bulgular}

Büyüme ile ilişkili olarak, hastanın boy kısalığı (orantılı veya orantısız) ve büyüme durumu mutlaka değerlendirilmelidir. Bir çocukta boy kısalığı veya büyüme geriliği olduğunu söylemek için; a) yaşa göre boyun, normalin üç persentil altında olması, b) büyüme hızının yaşına göre düşük olması, c) öngörülen boyun hedef boy sınırının altında olması, d) kemik yaşının boya ve yaşa göre uyumsuz ileri olması koşullarından en az birinin olması gerekir. Boy kısalığı orantılı veya orantısız şekilde olabilir. İskelet displazileri, istisnaları olmakla beraber, klinikte genellikle orantısız boy kısalığına neden olur. ${ }^{[14]}$ Osteogenezis imperfekta, bazı osteosklerotik hastalıklar, hipofozfatazya, bazı endokrinopatiler, nütrisyonel bozukluklar, prenatal başlangıçlı büyüme geriliği ve bazı genetik sendromlarda orantılı boy kısalığı söz konusudur. Hipotiroidizm, orantısız boy kısalığına neden olabilir. Multipl epifizyel displazide, çocukluk çağlarında normal büyüme eğrisinden belirgin bir sapma yaşanır ve boy kısalığı gelişebilir (üç persentil civarında veya hemen altında). Fizik muayenede orantısız kısalık hemen fark edilemeyebilir. Bu nedenle, bazı antropometrik ölçümler yapılmalıdır (Tablo 4). Bu ölçümler kapsamında; üst segment/alt segment oranı, oturma yüksekliği ve kulaç mesafesi ölçümleri önemlidir.

1. Üst segment/alt segment oranı: Üst/alt vücut oranlarına bakılması, iskelet displazisi tanısında çok yararlıdır. Üst ve alt segment ölçümleri, hasta ayakta veya yatar pozisyonda iken yapılabilir. Alt segment, pubik kemiğin üst orta kısmından ayak topuğuna kadar olan mesafedir. Üst segment, toplam uzunluktan alt segment uzunluğu çıkarılarak hesaplanır. Normal üst/alt segment değeri, beyaz ırkta yenidoğanlarda yaklaşık 1,75 iken, 8-10 yaşında 1,00'e, yetişkinlerde 0,95 'e düşer.

2. Oturma yüksekliği: Oturma yüksekliği, baş ve gövde uzunluğu ölçümünün doğru yapıldığı bir ölçüm olmakla birlikte, ölçüm sırasında özel bir ekipman gerektirmesi nedeniyle klinikte sık kullanılmaz. ${ }^{[14]}$

3. Kulaç mesafesi: Kulaç mesafesi, kollar horizontal olarak gergin bir şekilde her iki yana açıldığında iki el orta parmakları arasında oluşan mesafedir. Bu mesafe, normalde toplam boy uzunluğuna birkaç santimetredir. Kızlarda 10-11, erkeklerde 11-14 yaşlarına kadar, kulaç mesafesi boydan kısadır, sonraki yaşlarda kulaç boyu uzar. ${ }^{[15]}$ Eğer kulaç mesafesi hastanın boyuna yakın (boy $=$ kulaç \pm 5 $\mathrm{cm}$ ) değerlerde ise orantılı bir kısalıktan söz edilebilir. Vertebra büyümesini etkileyen bazı durumlarda da kulaç boydan daha uzun kalır; bu nedenle, kulaç mesafesi boydan uzun çıkan çocuklarda skolyoz muayenesi dikkatli yapılmalıdır.

Bazı lizozomal depo hastalıkları (mukopolisakkoridoz gibi) ve brakiyolmia gibi iskelet displazilerinde, gövdede kısalık söz konusudur. Bu yapılan ölçümlerin yanı sıra, üst ekstremite rizomelik kısalık açısından ayrıca değerlendirilmelidir. Bu değerlendirme sırasında şu ölçüm yapılır: Kol gövdeye yapışık, dirsek $90^{\circ} \mathrm{kıv}-$ rılmış durumda iken omuz-dirsek arası ve dirsek - 3 . metakarp arası mesafe ölçülür. Bu esnada eller yumuk, el ve kol aynı düzlemde bulunmalıdır. Normalde omuzdirsek/dirsek-metakarp oranı yaklaşık 1'dir, 0,98'in altında olması rizomelik kısalığı işaret eder. Tüm bu ölçümler yaş ile beraber değişim gösterir. Orantısız boy kısalığı; gövdede veya ekstremitede kısalık, ekstremitede kısalık ise bütün ekstremitelerde kısalık veya ekstremitenin bazı kısımlarında kısalık şeklinde olabilir. Orantısız kısalık radyolojik ve/veya klinik olarak saptanabilir. Radyolojik orantısızık ile klinik orantısızıı her zaman korelasyon içinde olmayabilir. Klinik değerlendirme sırasında cilt altındaki kemik uzunluğu değil cilt üzerindeki çizgiler ve cilt katlantıları rehber alındığından, yapılan ölçümler gerçek ekstremite uzunluğunu yansıtmıyor olabilir. Benzer şekilde, kıvrılmış bir uzun kemik, dışarıdan bakıldığında radyografik uzunluğuna göre çok daha kısa gözükecektir.

Fizik muayene sırasında ekstremite; proksimal segment (rizomelik; humerus ve femur), orta segment (mezomelik; radius, ulna, tibia ve fibula) ve distal segment (akromelik; eller ve ayaklar) olmak üzere üç kısımda incelenebilir. Mikromeli, tanım olarak bütün dört ekstremitenin ve ekstremite kısımlarının çok şiddetli kısa olduğu durumdur. Vertebrada patoloji olması durumunda "spondilo-" ön eki kullanılır. Farklı iskelet displazilerinde, farklı segmentler farklı derecelerde tutulmuş olabilir. Örneğin, akondroplazi ve hipokondroplazi gibi durumlarda ekstremite kısalığı, spondilodisplaziler ve skolyozla karakterize durumlarda ise gövde kısalığı ön plandadır. Kısa ekstremiteli şiddetli kısalıkta; kulaç mesafesi azalmış, üst/alt segment oranı artmıştır. Kısa gövdeli şiddetli kısalıkta ise kulaç mesafesi normaldir, üst/alt segment oranı azalmıştır. Eğer bir hastalık ekstremiteleri etkilemiş ise, hangi ekstremitenin hangi kısmının etkilendiğine dikkat edilmelidir. Ayırıcı tanıda bu basamak çok önemlidir.

\section{Büyüme ile ilişkili olmayan klinik bulgular}

İskelet displazili hastalarda büyüme ile ilgili olmayan bulgular da olabilir. Anormal eklem mobilitesi ve farkIı şekillerde açılanma deformiteleri sıktır ve genellikle 
simetriktir. Kafa tabanında ve vertebra pediküllerinde, büyüme defektleri spinal kanal genişliğini daraltabilir ve bu durum da spinal kord kompresyonuna neden olabilir. Kısa kostalar toraks hacmini azaltarak kısa gövdeli kondrodisplazisi olan hastalarda solunumun iş yükünü daha da arttırabilir. Yarık damak, yüksek dereceli kırma bozuklukları, konjenital kalp hastalıkları, immün yetmezlik ve böbrek fonksiyon bozuklukları da, eşlik eden diğer bulgular arasında yer alabilir. İskelet displazisi şüphesiyle yönlendirilen hastanın klinik değerlendirmesinde sistemik ve dismorfik bulguların gözden geçirilmesi önemlidir. ${ }^{[16]}$ Özellikle fontanel, burun köprüsü, orta yüz, filtrum, mandible, damak ve kulaklara dikkat edilmelidir. ${ }^{[9]}$ Bazen, dismorfik muayene ipuçları radyolojik değerlendirmeden önce klinik tanının konmasını sağlayabilir (Tablo 5). ${ }^{[16]}$ İskelet displazisi olan hastalara tanısal yaklaşım sırasında kullanılabilecek temel klinik veya radyolojik bulgular eşliğinde ayırıcı tanı örnekleri Tablo 6'da verilmiştir.

İskelet displazisi şüphesi olan hastalarda, mutlaka göz ve kulak-burun-boğaz muayenesi yaptırılmalıdır; el ve ayaklar dikkatli bir şekilde muayene edilmelidir. Postaksiyel polidaktili kondroektodermal displazi ve kısa kosta polidaktili sendromlarında; kısa, hipermobil radyal şekilde yer değiştirmiş başparmak diastrofik displazide; hipoplazik tırnaklar kondroektodermal displazide; kısa ve geniş tırnaklar kıkırdak-saç hipoplazisinde; pes ekinovarus Kniest displazisi, spondiloepifizyel displazi konjenita, Larsen sendromu, bazı osteogenezis imperfekta formları ve diastrofik displazide saptanabilir.

Bir kural olarak; multipl epifizyel displaziler doğumda veya hayatın ilk 1-2 yılı içinde tanı almaz. Doğumda, boy normal ve vücut kısımları orantılıdır. Bu kurala bir istisna, DTDST mutasyonları ile karakterize resesif geçişli multipl epifizyel displazide doğumda saptanabilecek pes ekinovarus bulgusudur. Sık rastlanan bir başvuru semptomu, en azından ilk zamanlarda kalça ve dizde, özellikle egzersiz sonrasında gelişen eklem ağrılarıdır.

Konjenital kalp hastalıkları; kondroektodermal displazide (MIM 225500) (ASD), kısa kosta polidaktili sendromlarında (izole VSD'de olmak üzere komplike çıkış yolu defektleri) veya Larsen sendromunda (VSD) saptanabilir. Gastrointestinal anomaliler nadirdir. Bununla beraber; konjenital megakolon (kıkırdak saç hipoplazisi MIM 250250), malabsorpsiyon sendromları (Schwachmann-Diamond sendromu MIM 260400) ve omfalosel (otopalatodijital sendrom Tip I MIM 311399, otopalatodijital sendrom Tip II MIM 304120 veya atelosteogenezis I MIM 108720) görülebilir. Anormal genital yapı; siliyopati, kampomelik displazi (MIM 211990,114290), omodisplazi Tip 1
(MIM 258315), omodisplazi Tip 2 (MIM 164745), Robinow sendromu (MIM 268310), Antley-Bixler sendromu (MIM201750) ve ağır kolesterol metabolizması bozukluklarında görülebilir.

\section{Radyolojik Değerlendirme}

İskelet displazilerinin ayırıcı tanısında radyografik incelemeler önemli bir yer tutar. Bu nedenle, öykü ve fizik muayeneden sonra hekimde iskelet displazisi yönünde bir şüphe uyanmış ise, bir çeşit "genetik iskelet taraması" şeklinde radyolojik tetkikler istenmelidir (Tablo 7). ${ }^{[17]}$ Bununla beraber; hastalarda radyolojik tetkikler planlanırken, pediatrik hastalarda kullanılan iyonize radyasyon dozunun mümkün olduğunca düşük sevilerde tutulması gerektiği göz önünde bulundurularak hareket edilmelidir. Orantılı boy kısalıklarında bütün iskelet sisteminin kemik taramasına gerek olmayıp, kemik yaşının belirlenmesinde sol el bilek grafisi yararlı olacaktır. Bununla beraber; orantılı boy kısalığı olan bir hastada dismorfik yüz bulgularının olması ve multipl konjenital anomalilerin saptanması durumunda modifiye bir kemik taraması planlanabilir. Kemik yaşı kişilerin erişkin boyları ile ilgili güvenilir tahminlere katkı sağlamasa da hastaların değerlendirilmeleri sırasında yararlı olabilir. Pek çok iskelet displazisi kemik matürasyonunda gecikme ile karakterize olsa da bazılarında (Desbuquois displazisi) karpal kemik yaşı ileridir.

Düz grafiler birçok konuda fikir vericidir. Her bir kemiğin büyüklüğü, yapısı ve şekli en ince ayrıntılarına kadar incelenmelidir. Erişkin hastalarda epifizin metafizle kaynaşmış olması tanıyı güçleştireceğinden, eğer varsa prepubertal radyografiler mutlaka değerlendirilmelidir. ${ }^{[13]}$ Grafilerde özellikle vertebra, ekstremite, pelvis ve kafatası dikkatli incelenmelidir. Ayrıca, lezyonların yerleşimi de önemlidir. Radyografiler elde edildikten sonra, grafilerin değerlendirilmeleri sırasında üç basamaktan oluşan bir yaklaşım önerilmektedir. ${ }^{[17]} \mathrm{Bu}$ yaklaşım sırasında radyografik bulgularla ilgili, varsa bir paternin ortaya çıkarılması tanıda anahtar rol oynayacaktır.

\section{Orantısızlığın değerlendirilmesi}

Orantısızlık hem klinik hem de radyografik olarak değerlendirilmelidir. Vertebra bulguları, platispondili ve kısa gövdeli boy kısalığı olup olmadığı hakkında fikir verecektir. Benzer şekilde, ekstremitelere bakarak rizomeli, mezomeli veya akromeli olup olmadığı söylenebilir. Orantısızlık radyografik olarak daha doğru bir şekilde değerlendirilmektedir. Klinik değerlendirme sırasında cilt katlantıları ölçümleri yanıltabilir. Rizomelik kondrodisplazi punktata rizomelik iskelet displazisine güzel bir örnek olarak verilebilir. Rizomelik 


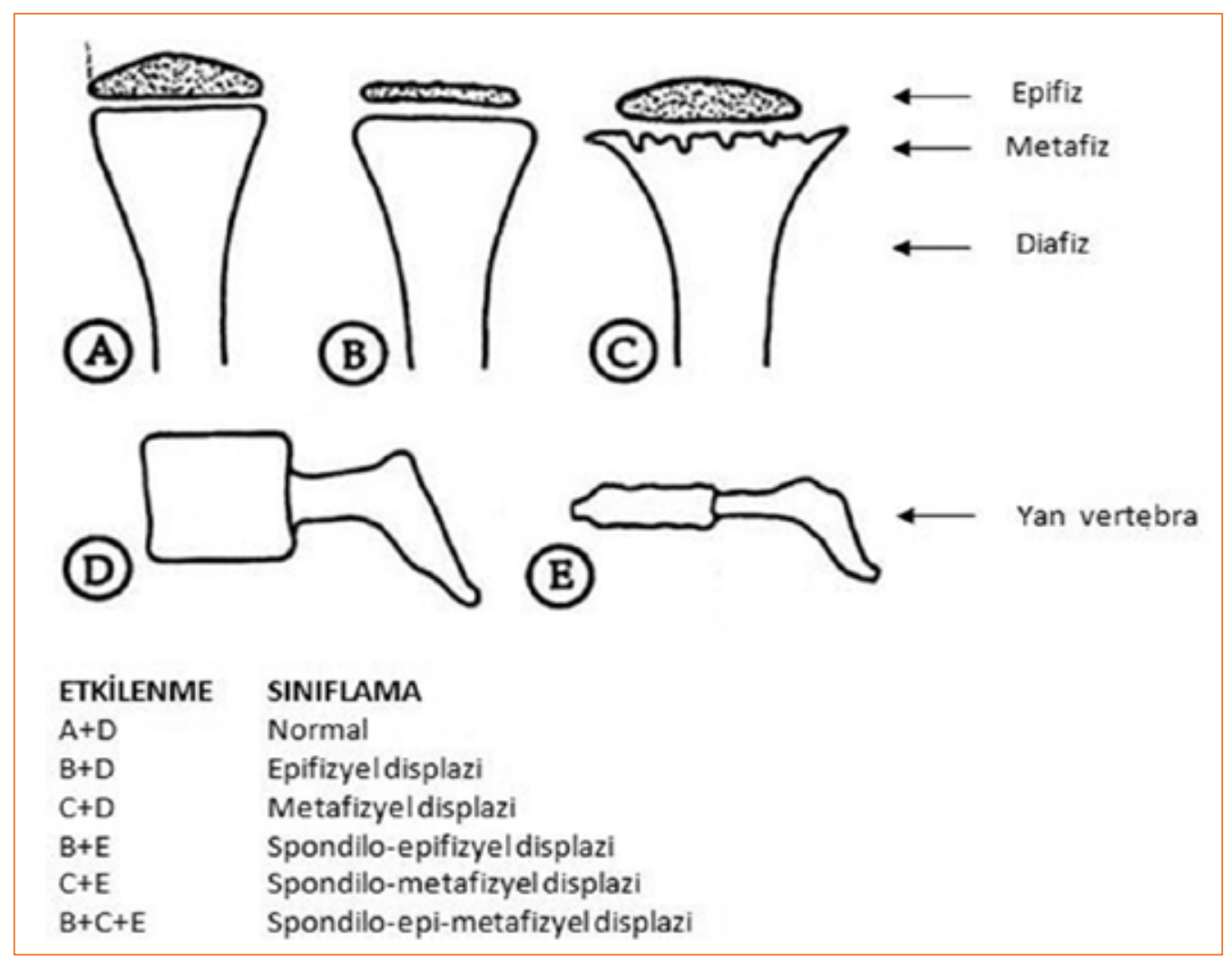

Şekil 1. Radyolojik sınıflama.

kısalık bulgusuna ilave olarak, punktat kalsifikasyonlar (stippling) ve vertebralarda koronal yarıklanma bulguları saptanabilir. Benzer punktat kalsifikasyonlar diğer bazı durumlarda da karşımıza çıkabilir (Tablo 8). Tek başına mezomeli bulgusunun uzun ve heterojen bir ayırıcı tanı listesi vardır. Akromeli bulgusunu fark etmek önemlidir. Tek başına akromeli bulgusunun saptanması durumunda; akromikrik displazi, akrodizostozis, geleofizik displazi ya da iskelet displazisi olmayan brakidaktiler düşünülebilir. Dördüncü metakarpal kemiğinde kısalık ile karakterize brakidaktili, Tip E Turner sendromu veya psödohipoparatiroidizmde saptanabilir. Orantılı akromelik kısalık bulgusunun olmaması, spondiloepifizyel displazi konjenita (MIM 183900) ve Tip II kollajenopatilerin pek çok tipinde saptanabilir bir bulgudur. ${ }^{[17]}$

\section{Epifizyel, metafizyel ve diyafizyel ossifikasyonların} değerlendirilmesi

İskelet displazilerinde; epifiz, metafiz ve diyafizlerin anormal gelişimi söz konusu olabilir. İskelet displazilerin adlandırmaları sırasında, genellikle kemiğin etkilenmiş kısımları kullanılmaktadır. Çok küçük ve/veya düzensiz ossifiye olmuş epifizlerin varlığında epifizyel displazilerden; geniş, düzensiz ve çanaklaşmış metafizlerin varlığında metafizyel displaziden; diyafizyel genişleme, kortikal kalınlaşma, kemik iliği alanında genişleme veya restriksiyon durumunda diyafizyel displazilerden söz edilebilir. Vertebranın izole bir şekilde tutulum gösterdiği ve büyüme plağında değişikliğin olmadığı durumlarda brakiyolmia gibi patolojiler düşünülmelidir. Uzun kemiklerin hangi kısımlarının etkilendiği, sınıflandırmada ve ayırıcı tanıda belirleyicidir (Şekil 1). Omurganın etkilenip etkilenmemesi de yine hastalık tiplendirmesindeki önemli ayırıcı noktalardandır (spondiloepifizyel ve spondilometafizyel gibi). Ekstremite segmentlerinin ve epifizyel büyüme plağının değerlendirilmesinin ardından, genetik iskelet taramasına dahil olan bütün yapılar en ince ayrıntılarına kadar incelenmeli ve saptanan bulguların daha önceden tanımlanmış herhangi bir iskelet displazi bulguları ile örtüşme gösterip göstermediği dikkatlice değerlendirilmelidir. Bu değerlendirme sırasında, bazı patognomik bulgular göz önünde bulundurulabilir. Bunlara örnek olarak; Schneckenbecken displazisinde sümüklü böcek şeklindeki iliak kemikler, Dyygve-MelchiorClausen sendromunda (MIM 223800) iliak krestte dantel görünümü, piknodisoztozisde mandibular 
açının kaybolması, wormian kemik ve akroosteolizis bulguları sayılabilir. ${ }^{[17]}$ Epifizlerde noktasal kalsifikasyonlar kondrodisplazi punktata için önemliyken, birden fazla kalkaneal ossifikasyon merkezi, yirmiden fazla hastalıkta görülebilmektedir. Multipl epifizyel displazi resesif formunda (MIM 226900), çift kat patellayı (double layered patella) gösterecek yan diz grafisi gerekebilir. ${ }^{[17]}$

\section{Normal varyantların patolojik olanlardan ayırt edilmesi}

Büyümekte olan iskelette normal varyantları patolojik olanlardan ayırt edebilmek için radyoloji alanında belli bir tecrübeye sahip olmak gerekir. Değerlendirme sırasında, hastalardaki bütün kemik yapılar, klinik ve eğer varsa dismorfik bulgular dikkate alınmalıdır. Bu basamakta, fizik muayene sırasında saptanan bazı ipuçları kullanılabilir. Bu noktada ciddi bir klinik ve radyografik değerlendirme, hekime hastanın klinik takipleri konusunda yardımcı olabilir. Kesin tanı almayan hastalarda bile, yapılacak basit bir radyografik sınıflama hastaların klinik takiplerinde çok yardımcı olacaktır. İskelet sisteminin etkilenmiş bölgeleri ayırıcı tanıda kolaylaştırıcı bir faktör olarak rol oynayabilir. Buna örnek olarak, kıkırdak-saç-hipoplazisi (MIM 250250) verilebilir. Bu displazide, diz metafizi yoğun bir şekilde etkilenirken kalça metafizi kısmen korunmuştur. Bu etkilenme paterni, kıkırdak-saç-hipoplazisinin (MIM 250250) diğer metafizyel displazileri ve nütrisyonel rikets ayırıcı tanısında kullanılabilir. Bu üç basamaktan oluşan değerlendirme sonrasında hastaya kesin bir tanı konulamazsa, klinik ve radyografik bulgular iskelet displazileri konusunda uzman diğer hekimlerle veya diğer gruplarla tartışılmalıdır.

Radyografik incelemeler sırasında karşımıza çıkabilecek bulgulardan bazıları şunlardır:

1. Konik şekilli epifiz: Konik şekilli epifizlerde distale göre bazal kısım daha geniştir. Bu epifizler metafizde bir çıkıntı ile ilişkili olup sıklıkla falankslarda bulunsalar da metakarpal kemiklerde de bulunabilir. Bugüne kadar, 38'den fazla konik şekilli epifiz çeşidi bildirilmiştir. Akromesomelik displazi Maroteaux tipi (MIM 602875) örnek olarak verilebilir. Bu displazide metakarpal kemik ve falankslarda konik şekilli epifiz görülür.

2. Kampomeli: Kampomeli (eğilmiş kemik), özgün bir bulgu değildir; geniş bir ayırıcı tanı listesi bulunur. Bunlar arasında; kampomelik displazi, Stuve-Wiedemann sendromu (MIM 601559), Osteogenezis imperfekta ve iskelet displazisi dişındaki bazı diğer durumlar (Meckel-Gruber sendromu ve diğer fetal hipokinezi ile karakterize durumlar) sayılabilir. Kampomelik displazide (MIM 211990,114290), femur ve tibiada eğilme ve üstteki cilt kısmında gamze saptanır. Daha sık saptanan diğer radyografik bulgular arasında; hipoplastik/aplastik skapula, hipoplastik torakal vertebra pediküller ve 11 çift ince kosta sayılabilir. Kampomelik displazi (MIM 211990,114290) ve Stuve-Wiedemann sendromunda (MIM 601559), ekstremitelerde kampomeli görülebilir.

3. Osteopeni: Kemik yoğunluğunun radyografiler aracılığı ile değerlendirilmesi, subjektif bir değerlendirme olsa da ayırıcı tanıda yardımcı olabilir. Yoğun kemik yapısı osteopetrozis ve piknodisoztozis gibi durumlarda saptanırken, osteopeni bulgusu osteogenezis imperfekta ve hipofosfatazyada (MIM 146300,241500) saptanabilir. Osteogenezis imperfektanın tüm tiplerinde, ağır hipofosfatazyada ve osteopetrozis gibi osteosklerotik hastalıklarda kemik kırıklarının görülebileceği unutulmamalıdır.

4. Platispondili: Aksiyel iskelette vertebra yüksekliğinin azaldığı ve endplate düzensizliğinin olduğu durumları ifade etmek için kullanılan bir terimdir. Spondiloepifizyel displazi ve brakiyolmiada platispondili bulgusu görülebilir. Omurga grafilerinde, sadace platispondili bulgusu değil pek çok bulgu saptanabilir. Yenidoğan döneminde, Kniest displazisi ve kondrodisplazi punktatanın farklı formlarında multipl koronal yarıklanmalar saptanabilir. Dyygve-Melchior-Clausen sendromunda (MIM 223800) "çift hörgüç" bulgusu görülebilir. İskelet displazisi şüphesi ile başvuran bir hastanın değerlendirilmesi sırasında, servikal bölgeye eşlik edebilecek ciddi servikal vertebral anomaliler nedeniyle özellikle dikkat etmek gerekir (Tablo 9). ${ }^{[14]}$

\section{Dördüncü Boyut}

Radyografik bulguların değerlendirilmeleri sırasında dördüncü boyut, yani zaman içinde bulguların değişebileceği faktörü mutlaka göz önünde bulundurulmalıdır. İskelet displazilerinde radyografik bulguların statik olmadığı söylenebilir. Bu nedenle, bazı durumlarda radyografik bulguları belli aralıklarla incelemek gerekebilir. Spondiloepifizyel displazi tarda'da "hörgüç" vertebra bulgusu adolesan dönemine kadar saptanmayabilir. Sponastrime displazide, lomber vertebradaki değişiklik platispondili şeklinde başlayıp zaman içinde vertebral cisimlerin arka kısımlarında bikonkav deformite olarak değişim gösterir. Bunun tersi şekilde, bazı iskelet displazilerinde daha erken yaşlarda tanı koyduran radyografik bulgular zaman içinde kaybolabilir. Örneğin, spondiloepimetafizyel displazinin klasik bir örneği olan psödoakondroplazide, çocukluk yaşlarında lomber vertebrada anterior beaking, düzensiz küçük epifizler ve metafizyel çanaklaşma çok tipiktir. 
$\mathrm{Bu}$ patern, psödoakondroplazi tanısı için yeterlidir. Psödoakondroplazi tanısını koymak, epifizlerin kapandığı ve vertebralardaki anterior beaking bulgusunun nonspesifik platispondili bulgusu ile yer değiştirdiği erişkin dönemlerde çok daha zordur.

\section{Morfolojik İncelemeler}

Kondroosseöz dokunun morfolojik incelemesi, sıkça kullanılan bir yöntem olmasa da, tanıda önemli bir yere sahiptir. Birçok iskelet displazisinde spesifik anomaliler gösterilmiştir. ${ }^{[18]}$ Kıkırdak kemik morfolojisi ayrıcı tanıda çok yol gösterici olabilmektedir. Bu inceleme için büyüme plağı bölgesinden örnek alınabilir. ${ }^{[14]}$ Perinatal ölümle sonuçlanan olgularda bu örneklem otopsi ile, diğer hastalarda elektif operasyonlar esnasında alınabilir. iliak krestten biyopsi almak en uygunudur. ${ }^{[14]}$ İskelet displazilerine yaklaşımda yapılması önerilen tetkikler Tablo 10'da gösterilmiştir.

\section{ISKELET DISPLAZILERINDE SINIFLANDIRMA}

İskelet displazileri ile ilgili ilk sınıflamalar tanımlayıcı ve klinik verilere dayalı yapılmış iken günümüz sınıflandırmaları klinik, radyografik, morfolojik, biyokimyasal ve moleküler veriler birlikte kullanılarak yapılmaktadır. ${ }^{[1]} \mathrm{Bu}$ sınıflandırmaya göre iskelet displazileri; ilgili tek gen veya gen grupları ile (FGFR3 kondrodisplazi grubu veya sülfasyon bozuklukları grubu), belirli bir fenotipik özellik ile (multipl eklem dislokasyonları grubu) veya bazı radyografik bulgular (metafizyel displazi grubu veya "slender" kemik displazi grubu gibi) yardımıyla tanımlanmaktadır. Uluslararası Nozoloji her beş yılda bir iskelet displazisi konusunda uzman bir ekip tarafindan revize edilmektedir. Uluslararası Nozolojinin 2015 yılında yayımlanan güncel versiyonuna göre klinik, radyografik ve moleküler kriterlere göre 42 grup altında incelenen toplam 364 gen defektinden en az birinin etken olarak gösterildiği 436 genetik iskelet hastalığı tanımlanmıştır (Tablo 11).

İskeletin genetik hastalıkları moleküler-patogenetik etiyoloji açısından da sınıflandırılabilir. ${ }^{[12,13]}$ Bu sınıflama, pratik kullanımda olan ve belirli aralıklarla revizyondan geçirilen Uluslararası Nozolojiye bir alternatif olarak değil, tamamlayıcı bir rehber olarak geliştirilmiştir. Bu sınıflamaya göre, genetik iskelet hastalıkları yedi alt gruba ayrılabilir (Tablo 12). Klinik ve moleküler korelasyonların giderek artan bir şekilde gerçekleştirilmesi, iskelet gelişimi ile ilgili metabolik ve sinyal yolaklarında yer alan gen/genlerin ortaya çıkarılmasına, ilgili yolakların daha iyi anlaşılmasına ve elde edilen bilgiler doğrultusunda potansiyel tedavi hedeflerinin belirlenmesine katkı sağlayacaktır.

\section{PATOFIZYOLOJi}

İskelet displazilerinde mutasyonlar farklı mekanizmalar aracılığıyla etkilerini gösterir. Mutasyonların çoğu, kıkırdak matriks proteinlerini kodlayan genlerde iki allelden birinin etkilendiği mutasyonlar şeklindedir. $\mathrm{Bu}$ tür mutasyonlar, genellikle dominant negatif etki mekanizması ile etkilerini gösterir. Mutant allelin kodladığı protein, multimerik moleküllerin bir araya gelmesine ve fonksiyon göstermesine olumsuz etki eder. Bu konu ile ilgili olarak, Tip II kollajenopati grubu güzel bir örnek oluşturur. Kollajen Tip II, üç zincirinden oluşan üçlü heliks yapıda olan bir moleküldür. Bu zincirler kollajen Tip II geni olan COL2A1 tarafindan kodlanır. Normal ve mutant allelerden kodlanan zincirler üçlü heliksi oluşturmak için bir araya geldiklerinde, çoğu molekül en az bir mutant zincir içerir. Disfonksiyonel bir molekül oluşturmak için gereken mutant zincir sayısı tam olarak bilinmese de, teoride bu sayı mutasyon tipine bağlı olarak en az bir zincir bile olabilmektedir.

Kollajen Tip X'u içeren mutasyonlar biraz daha farklıdır. Zincir tanıma bölgesinden sorumlu olan kollajen Tip X'da bir mutasyon olması durumunda, zincirler bir araya gelip fonksiyonel bir kollajen molekülü oluşturamaz. Bunun sonucunda mutant zincirlerden hiçbirisi oluşmakta olan molekülün yapısı içine giremez. Mutant allelin ürünleri fonksiyonel değilken, normal allelin ürünleri normal fonksiyon göstermekte yetersizdir. Etkili olan genetik mekanizmadan bağımsız olarak, mutasyonlar iskelet gelişimi ve lineer büyümesinden sorumlu endokondral ossifikasyona zarar verir. İskelet displazilerinde endokondral ossifikasyonun gerçekleştiği anatomik yapıda, yani büyüme plağında, pek çok morfolojik anormallikler meydana gelir. Bugüne kadar iskelet displazilerinin etiyolojisi ile ilişkili olarak; kıkırdak matriks proteinleri, transmembran reseptörler, iyon taşıyıcı moleküller ve bazı transkripsiyon faktörleri kodlayan gen/genlerdeki mutasyonlar tanımlanmıştır (Tablo 13).

\section{MOLEKÜLER GENETIK}

İskeletin genetik hastalıklarında genetik etiyolojinin ortaya çıkarılması; klinik ve radyografik bir tanıyı kesinleştirme, resesif bir hastalık için taşıyıcılık durumunu belirleme, aynı aile içinde bulunan ve analiz edilen hastalık açısından risk altında bulunan diğer aile bireylerini saptama ve prenatal tanı verme açısından büyük öneme sahiptir. Moleküler genetik alanında kullanılan teknolojideki ilerlemeler sayesinde iskelet displazilerinin yaklaşık üçte ikisinin genetik etiyolojisi ortaya çıkarılmıştır (Tablo 14).. ${ }^{[9]}$ Özellikle tüm genom tekli nükleotid polimorfizm haritalaması, karşılaştırmalı genomik hibridizasyon dizin analizi, tüm ekzom veya tüm 
genom yeni nesil dizileme gibi teknolojilerin kullanıldığı çalışmalar sonucunda, iskelet büyüme ve gelişimindeki bozuklukların yol açtığı genetik iskelet hastalıklarının çoğunun etiyolojisi ortaya çıkarılabilmiştir. ${ }^{[20]}$ Etkinliği daha yüksek, maliyeti daha düşük dizileme teknolojileri geliştirildikçe, tüm genom dizileme tekniği muhtemelen en tercih edilen yöntem haline gelecektir.

Klinik ve radyografik bulgularla ayırt edemediğimiz ancak farklı genetik etiyolojiye ve tekrar etme riskine sahip genetik iskelet hastalıklarında, moleküler etiyolojinin ortaya çıkarılması önemlidir. Örneğin, daha önceki gebeliğinde şüpheli bir iskelet displazisi öyküsü olan ve kaybedilen bir fetüsta etiyolojinin ortaya çıkarılmasının kritik bir önemi olacaktır. Aileye verilecek genetik danışma, etiyolojinin akondrogenezis Tip $1 \mathrm{~b}$ (resesif kalıtım, tekrar etme riski \%25) veya akondrogenezis Tip 2 (de novo dominant, tekrar etme riski <\%1) olmasına göre değişiklik gösterecektir. Benzer şekilde, osteogenezis imperfektalı bir yenidoğana klinik yaklaşım, altta yatan moleküler etiyolojiden bağımsız bir şekilde benzerlik gösterse de, ailesel tekrarlama riski ve uzun dönem prognoz moleküler etiyoloji ve klinik sınıflamaya göre değişkenlik gösterebilir. Örneğin, ağır progresif osteogenezis imperfekta tipik olarak normal zeka ile ilişkiliyken, aynı radyografik özellikleri paylaşan başka bir osteogenezis imperfekta formu (homozigot WNT1 mutasyonu) zeka geriliğine neden olabilir. ${ }^{[21]}$

İskelet displazisi tanısının aile öyküsü, klinik ve radyografik bulgulara dayanarak konmasının ardından, bahsi geçen moleküler genetik testler (iskelet displazisi gen panelleri) ülkemiz koşullarında da pek çok laboratuvarda yapılabilmektedir. İskelet displazilerinde geleneksel yaklaşım klinik ve radyografik bulgular doğrultusunda moleküler testlerin planlanması şeklinde olsa da, bugün bazı merkezlerde önce moleküler testler yapılmakta, ardından saptanan bulgular klinik anlam ve nedensellik açısından araştırılmaktadır. Böylesi bir yaklaşımın klinik değerlendirmenin önüne geçip geçmeyeceği tartışmalıdır. ${ }^{[9]}$

Genetik iskelet hastalıklarının moleküler tanısı, özellikle hem lokus hem de allelik heterojenitesi olan iskelet displazilerinde oldukça önemlidir. ${ }^{[9]}$ Bazı hastalıklar için, mutasyonun tipi ve lokalizasyonu hastalığın doğal seyri ile ilgili fikir verebilir. Örneğin, nonsense veya protein kaybı mutasyonları missense mutasyonlara göre farkIı şiddette hastalığa neden olabilir. Kollajen Tip I proteinini kodlayan COL1A1 ve COL1A2'de nonsense mutasyonları hafif bir hastalığa yol açarken ${ }^{[22]}$, aynı gendeki missense mutasyonlar çok daha ağır ve progresif bir hastalığa neden olur. ${ }^{[23]}$ Osteogenezis imperfekta hastalarının \%90'ında kollajen Tip I'de mutasyon saptanırken, \%10 hastada kollajen Tip I'in işlenmesinden ve trafiğinden sorumlu olan ve resesif şekilde kalıtılan gen mutasyonları söz konusudur. ${ }^{[24]}$ Osteogenezis imperfekta gibi tek bir iskelet displazisi grubunda, genetik etiyolojide yer alan ve resesif kalıtılan çok sayıda genin artan bir sıklıkta ortaya çıkarılması, moleküler genetik alanında yaşanan hızlı gelişmelerin güzel ve çarpıcı bir örneğidir.

\section{TEDAVI VE UZUN DÖNEM IZLEM}

İskelet displazilerinin tedavisinde birinci basamak; doğru tanıyı koymak ve hastanın takibini multidisipliner (kadın doğum, yenidoğan, pediatri, pediatrik genetik, klinik genetik, ortopedi, beyin cerrahisi, kulak-burun-boğaz, pediatrik endokrinoloji, fizik tedavi ve rehabilitasyon, pediatrik nöroloji, radyoloji) bir şekilde yapmaktır. Hastanın tanısı, hastalığın prognozunun ve eşlik edebilecek diğer tıbbi ve cerrahi sorunların belirlenmesinde kritiktir. Bir iskelet displazisi ile etkilenmiş prematüre veya yenidoğan bir bebekteki klinik bulgular, altta yatan iskelet displazisine göre farklılık gösterecektir. Akondrogenezis Tip 1b veya tanatoforik displazi oldukça kötü bir prognoza sahipken, spondiloepifizyel displazi konjenita veya diastrofik diplazi yenidoğan dönemi dışında iyi prognoza sahiptir. İskelet displazilerinde bugüne kadar rutin kullanımda olan farmakolojik bir tedavi bulunmamaktadır. Bununla beraber, bu konu ile ilgili bazı umut verici aday çalışmalar söz konusudur. ${ }^{[20]}$ Akondroplazi ile ilgili olarak lineer kemik büyümesinde C-tipi natriuretik peptidin kullanıldığı klinik çalışmalar devam etmektedir. ${ }^{[25]}$ Bazı mukopolisakkaridoz tiplerinde kullanılan enzim tedavileri akciğer fonksiyonlarını iyileştirebilir. Fakat, bu tedavi iskelet ve eklem bozukluklarına karşı etkili değildir. ${ }^{[26]}$ Büyüme hormonu tedavisi büyüme hızını arttırsa da, akondroplazi ve idiyopatik boy kısalığı gibi durumlarda, final boyda belirgin bir iyileşme olmaz. ${ }^{[27]}$ Bazı cerrahi işlemler bazı durumlarda ekstremite uzunluğunu arttırabilse de, bu tür cerrahi işlemler sayıca pek çoktur ve maliyeti yüksektir. Bunun yanı sıra, bu tür işlemler çocukluk çağının büyük bir kısmını tıbbi bakıma adamayı gerektirir. ${ }^{[14]}$ İskelet displazili hasta izleminde dikkat edilmesi gereken bazı önemli noktalar bulunmaktadır. Bu kişilerde birçok morbidite, tahmin edileceği gibi, iskelet anomalilerinden kaynaklanmaktadır. Akondroplazide, kafa kaidesindeki kemikleşmenin normalden kısa olması, küçük foramen magnum oluşumuna ve spinal kord basısına yol açabilmektedir. Odontoid hipoplazi ve diğer servikal anomali (subluksasyon gibi) ile karakterize hastalıklarda (Morquio hastalığı, Tip II kollajenopatiler, SMD Kozlowski tipi, metatrofik displazi ve Larsen sendromu gibi), düzenli aralıklarla, özellikle çocukluk döneminde C1-C2 ilişkisini değerlendiren radyografiler çekilmelidir. Genu varum veya genu valgum da 
sık görülen anomaliler arasında olup, şiddetli diz veya ayak bileği ağrısına neden olarak, hastada osteotomiye gereksinim duyulabilmektedir. Hastalara miyo$\mathrm{pi}$, vitreus veya retina dejenerasyonu ve glokom gibi durumlar açısından aralıklı göz muayenesi yapılmalıdır. Orta yüz hipoplazisi bulgusu, artmış kulak enfeksiyonlarına bir yatkınlık yaratabilir. Artmış enfeksiyon sıklığı, anormal stapes ve foramen magnum stenozu (akondroplazi, hipokondroplazi, diastrofik displazi, metatrofik displazi) sonucunda duyma kaybı gelişebilmektedir. Bu nedenle, aralıklı kulak-burun-boğaz muayenesi ve işitme testi uygun olacaktır. Hastadaki bulgular göz önünde bulundurularak; konuşma terapisi, mesleksel terapi veya fizyoterapi önerilebilir. İskelet displazili bireylerde, temas gerektiren sporlardan ve ekleme stres oluşturacak aktivitelerden özellikle kaçınılmalıdır. Kişilerde kilo kontrolü sağlanmalı ve obeziteye karşı dikkatli olunmalıdır. Hastalar düzenli aralıklarla diş hekimi kontrolünden geçirilmelidirler. İmmün sistemi ile ilgili patolojisi olmayan çocukların aşı programlarına normal şekilde devam edilmelidir.

\section{PRENATAL TANI}

Görüntüleme yöntemleri ve moleküler testlerde elde edilen gelişmeler sonucunda, iskelet displazilerinin prenatal dönemde tanınabilirliği hızı bir artış göstermiştir. ${ }^{[9,11]}$ Perinatal dönemde ölümcül olan iskelet displazilerinin pek çoğu fetal US ile saptanabilmektedir. İki veya üç boyutlu US'nin kullanıma girmesi ile anormal iskelet elemanlarını tespit etmek kolaylaşmış, hatta ayırıcı tanı yapmak mümkün olmuştur. Birçok ülkede 2. trimester US'si konjenital anomali taramasında rutindir. Bununla beraber, prenatal iskelet displazisi tanısı üçüncü trimester ya da doğuma kadar gecikebilmektedir. ${ }^{[9]}$ Rutin US ile iskelet displazilerinin doğru prenatal teşhisi \%40'a yaklaşmaktadır. ${ }^{[11]}$ Özellikle US'de yapılan ölçümler beş persentil veya -2 standart sapma (SS) altında ise iskelet displazilerinden şüphelenilmelidir. Böyle bir şüphe uyandığında, hasta ve ailesi iskelet displazileri konusunda tecrübe sahibi bir merkeze yönlendirilmelidirler.

Prenatal US ile iskelet displazisi şüphesi uyanmışsa, mevcut durumun ölümcül olma olasılığı mutlaka tespit edilmelidir. Bu amaçla, femur uzunluğu ile karın çevresi oranı, dar toraks ve azalmış kemik dansitesi perinatal letalite tahmini için kullanılır. Dar göğüs, pulmoner hipoplaziye yol açarak ölüme neden olabilir. Göğüs çevresi / abdomen çevresi <0,6, femur uzunluğu/abdomen çevresi $<0,16$ ise, mortalite için artmış risk söz konusudur. ${ }^{[9]}$

Gebeliğin sıklıkla daha ileri haftalarında saptanan iskelet displazileri, genellikle daha hafif bir klinik ile karakterizedir. Bu hastalarda genellikle ağır solunum sıkıntısı beklenmez ${ }^{[9]}$; akondroplazi, spondiloepifizyel displazi konjenita, bazı osteogenezis imperfekta formları örnek olarak verilebilir. Bu tür iskelet displazilerinde, büyüme eğrileri 20. gebelik haftasına kadar normal giderken 3. trimesterde birden düşme gösterir. Bunun nedeni, bu hastalıkların çoğundaki defektin en çok 3 . trimesterde aktif olan endokondral ossifikasyonda olmasındandır (kondensasyon veya daha önceki süreçlerde belirgin bir patoloji yoktur). ${ }^{[28]}$ Pek çok aile, iskelet displazisi tanısının doğumda mı konduğunu bilmek isteyecektir. Bu nedenle, ailelere genetik danışma sırasında bu konu ile ilgili açıklamalarda bulunmak yararlı olacaktır.

İskelet displazisinin erken saptanmasının (kesin tanısı olsun veya olmasın) birtakım avantajları vardır. Bunlar arasında; hasta ve ailesinin farkındalık düzeylerini arttırarak duruma hazırlık yapmaları, gerekli konsültasyonların planlanması ve moleküler tanıya yönelik yeterli ve gerekli materyallerin elde edilmesi sayılabilir. Bu durum, ölümcül olmayan ama yenidoğan döneminde ağır klinik ile karakterize bir iskelet displazisi durumunda özellikle önemlidir.

In utero radyografiler, günümüzde görüntü kalitesizliği, radyasyon riski ve yorum zorluğu nedeniyle tercih edilmemektedir. Vertebral bir patolojiden şüpheleniliyorsa, fetal manyetik rezonans (MR) görüntüleme; yüz anomalisi şüphesi varsa üç boyutlu US denenmelidir. ${ }^{[28]}$ Daha önce moleküler tanı almış bebek öyküsü olan ailelerde koryon villus örneklemesi veya amniyosentez ile fetal DNA örneği elde edilmelidir. Eğer anne ve/veya baba etkilenmiş bireyler ise, o zaman direkt olarak moleküler çalışma yapılabilir. Yine, ebeveynlerin birden fazla mutasyona sahip oldukları biliniyor ise moleküler analiz yapılabilir. Prenatal saptanmış tüm iskelet displazili fetusların klinik, radyolojik (radyografi ve US) ve mümkünse otopsi ile incelenmeleri (kıkırdak ve kemik histolojisi, patolojik bulgular) ve çalışmalar doğrultusunda planlanacak moleküler testlere yönelik biyolojik materyal (genomik DNA, fibroblast kültürü) elde edilmesi oldukça kritiktir. İndeks olgu ile beraber, ebeveynlerin de DNA örnekleri mutlaka alınmalıdır. Bugün prenatal tanı kapsamında kullanılmakta olan US ve bazı maternal serum tarama testlerinin yanı sıra, maternal kan örneğinden bazı Mendelyen hastalıkların test edildiği girişimsel olmayan yöntemler de (maternal kan örneğinden cell-free fetal DNA) kullanılmaya başlanmıştır. Birinci trimesterde kullanılan maternal kan örneğinden cell-free fetal DNA yöntemi, özellikle kopya sayısı değişiklikleri olmak üzere, anöploidilerin tespit edilmesinde yararlıdır. ${ }^{[29]}$ Anne kan örneğinden elde edilen fetal cell-free DNA fraksiyonunda de novo FGFR3 
mutasyonlarının (tanatoforik displazi) saptanması ile ilgili bildirilen raporlar, bu teknolojinin gelecekte özellikle de novo mutasyonların neden olduğu otozomal dominant kalıtım gösteren iskelet displazilerinin teşhisinde kullanılabileceğine işaret etmektedir. ${ }^{[30]}$

\section{SONUÇ}

İskelet displazileri klinik ve genetik etiyoloji açısından oldukça heterojen bir grup hastalıktır. Ülkemizde akraba evliliklerinin sık görülmesi nedeniyle, bu hastalık grubu orantısız boy kısalıkları arasında dikkate değer bir orana sahiptir. Bununla birlikte, iskelet displazileri konusunda deneyim sahibi uzman ve merkez sayısının yeterli olmaması nedeniyle, bu konuda bilgi ve tecrübe eksikliği yaşanmaktadır. Bu durum, hastaların tanılarında gecikmeler yaşanmasına, artmış morbiditelere ve nedeni bilinmeyen bebek ölümlerine neden olabilmektedir. Bu nedenle, hekimlerin özellikle şiddetli ya da orantısız boy kısalığı olan çocukların ayırıcı tanıları sırasında iskelet displazilerini göz önünde bulundurmaları, sık görülen iskelet diplazileri ve bu displazilere eşlik edebilecek morbiditeler hakkında bilgi sahibi olmaları ve gerekli durumlarda tecrübe sahibi diğer merkezlerle iletişime geçmeleri hayati öneme sahiptir.

Tablo 1. Dizostozis ve iskelet displazilerinin genel özellikleri

\begin{tabular}{|c|c|c|c|c|}
\hline & \multicolumn{2}{|c|}{ Dizostozisler } & \multicolumn{2}{|c|}{ İskelet displazileri } \\
\hline & Primer & Sekonder & Primer & Sekonder \\
\hline Etkilenmiş yapılar & \multicolumn{2}{|c|}{ Organ olarak iskelet elemanları } & \multicolumn{2}{|c|}{ Doku olarak kıkırdak ve/veya kemik } \\
\hline Dağılım & \multicolumn{2}{|c|}{$\begin{array}{c}\text { Genellikle simetrik, bazen hafif şekilde asimetrik olabilir. } \\
\text { Bazı durumlarda tek taraflı da olabilir. }\end{array}$} & \multicolumn{2}{|c|}{ Genellikle simetrik } \\
\hline Etkilenmenin olduğu dönem & Organogenezis & Büyüme dönemi & \multicolumn{2}{|c|}{ Büyüme dönemi } \\
\hline Ekstraosseöz/çevresel neden & Hayır & Evet & Hayır & Evet \\
\hline Metabolik/hormonal neden & \multicolumn{2}{|r|}{ Hayır } & İntrensek & Ekstrensik \\
\hline Malign transformasyon & \multicolumn{2}{|r|}{ Hayır } & Nadir ama mümkün & Henüz bilinmiyor \\
\hline
\end{tabular}

Tablo 2. Dizostodisplazi örnekleri

\begin{tabular}{lccl}
\hline Hastalık adı & Kalıtım paterni & Gen & Protein \\
\hline Kleidokraniyal dizostozis & OD & RUNX2 & Runt transkripsiyon faktörü \\
Kampomelik displazi & OD & SOX9 & SOX9 transkripsiyon faktörü \\
Spondilomegaepifizyel metafizyel displazi & OR & NKX3-2 & NKX3-2 homeobox transkripsiyon faktörü \\
Grebe/Hunter-Thompson displazi & OR & GDF5 & Growth and differentiation factor 5 \\
Nail-patella sendromu & OD & LMX1B & Lmx1b homeodomain protein \\
\hline
\end{tabular}

OD, otozomal dominant; OR, otozomal resesif.

Tablo 3. Prenatal dönemde veya yenidoğan döneminde saptanan iskelet displazileri

\begin{tabular}{ll}
\hline $\begin{array}{l}\text { Yenidoğan döneminde veya } \\
\text { postnatal ilk aylarda saptanan iskelet displazileri }\end{array}$ & $\begin{array}{l}\text { Prenatal dönemde } \\
\text { 'genellikle' ölümcül olan iskelet displazileri }\end{array}$ \\
\hline Akondroplazi (heterozigot mutasyon) & Akondroplazi (homozigot mutasyon) \\
Osteogenezis imperfekta (Tip I, III, IV) & Osteogenezis imperfekta Tip II \\
Spondiloepifizyel displazi konjenita & Kısa kosta polidaktili (farklı tipleri) \\
Diastrofik displazi & Akondrogenezis (farklı tipleri) \\
Ellis-van Creveld sendromu & Kampomelik displazi \\
Kondrodisplazi punktata (bazı formları) & Kondrodisplazi punktata (rizomelik form) \\
Kniest displazi & Tanatoforik displazi \\
Metatrofik displazi & Hipofosfotasya (konjenital form) \\
Langer mesomelik displazi & Dissegmental displazi
\end{tabular}


Tablo 4. Orantısız boy kısalığında antopometrik ölçümler

\begin{tabular}{lll}
\hline & Kısa ekstremiteli boy kısalığı & Kısa gövdeli boy kısalığı \\
\hline Boy & Ortalamanın 2 standart sapma altında & Ortalamanın 2 standart sapma altında \\
Kulaç boyu & Azalmış & Normal (yaşa göre) \\
Üst segment / Alt segment & Artmış & Azalmış
\end{tabular}

Tablo 5. İskelet displazilerinde tanıya yardımcı olabilecek belirti ve bulgular

\begin{tabular}{|c|c|}
\hline Belirti ve bulgular & İskelet displazisi \\
\hline \multicolumn{2}{|l|}{ Kafa } \\
\hline Makrosefali & Akondroplazi, hipokondroplazi \\
\hline Büyük fontaneller, geniş sütürler & Kleidokraniyal displazi, piknodizostozis \\
\hline Yonca yaprağı kafatası & Tanatoforik displazi \\
\hline Kraniyosinostozis & Tanatoforik displazi \\
\hline Hipertelorizm & Robinow sendromu \\
\hline \multicolumn{2}{|l|}{ Burun } \\
\hline Düşük burun köprüsü & Kondrodisplazi punktata, akondroplazi, akrodizostozis \\
\hline \multicolumn{2}{|l|}{ Diş } \\
\hline Natal dişler & Ellis-van Creveld sendromu \\
\hline Dentinogenezis imperfekta & Osteogenezis imperfekta \\
\hline Diş sement hipoplazisi & Hipofosfatazya \\
\hline Diş fazlalığı & Kleidokraniyal displazi \\
\hline Geç diş çıkması/enamel hipoplazisi & Piknodizostozis \\
\hline Konik şeklinde diş & Ellis-van Creveld sendromu \\
\hline Oligodontia & Ellis-van Creveld sendromu \\
\hline \multicolumn{2}{|l|}{ Ağız boşluğu } \\
\hline Yarık damak & Tip II kollajenopatiler, kampomelik displazi, diastrofik displazi, atelosteogenezis grubu \\
\hline Oral frenula & Ellis-van Creveld displazisi, oral fasyal dijital sendrom \\
\hline \multicolumn{2}{|l|}{ Göz } \\
\hline Retinitis pigmentoza & Saldino-Mainzer displazisi \\
\hline Katarakt & Kondrodisplazi punktata, Stickler sendromu \\
\hline Ciddi miyopi & Tip II kollajenopatiler \\
\hline Mavi sklera & Osteogenezis imperfekta \\
\hline Retinal ayrilma & Stickler sendromu \\
\hline \multicolumn{2}{|l|}{ Kulak } \\
\hline Akut pinna inflamasyonu & Diastrofik displazi \\
\hline Kulakta kist & Diastrofik displazi \\
\hline \multicolumn{2}{|l|}{ Saçlar } \\
\hline Seyrek saçlar & Kıkırdak-saç hipoplazisi, trikorinofalangeal displazi \\
\hline \multicolumn{2}{|l|}{ Cilt } \\
\hline Fazla cilt katlantıları & Akondroplazi, hipokondroplazi \\
\hline İktiyoziform eritroderma & Kondrodisplazi punktata \\
\hline Akantozis nigrikans & Ağır akondroplazi, hipokondroplazi \\
\hline \multicolumn{2}{|l|}{ Tirnak } \\
\hline Yarık tırnaklar & Kondrodisplazi punktata, Conradi-Hünermann tipi \\
\hline Hipoplastik tırnaklar & Ellis-van Creveld displazisi, kondrodisplazi punktata, brakitelefalanjik tip \\
\hline
\end{tabular}


Tablo 5 (devam). İskelet displazilerinde tanıya yardımcı olabilecek belirti ve bulgular

\begin{tabular}{ll}
\hline Belirti ve bulgular & İskelet displazisi \\
\hline Eklem & Rizomelik tip kondrodisplazi punktata, jeleofizik displazi, dizostozis multipleks grubu \\
Kontraktür & Kıkırdak-saç hipoplazisi, psödoakondroplazi \\
Hiperlaksite & Larsen sendromu, Desbuquois displazisi, psödodiastrofik displazi \\
Dislokasyonlar &
\end{tabular}

\section{Ekstremite}

Asimetri

Kırık

Kısa abdukte başparmaklar

Eğri kemikler

Pes ekinovarus

Polidaktili

Kamptodaktili

Pretibial cilt gamzeleri

Club foot

Omuz

Aplastik/hipoplastik klavikula

\section{İç organlar}

Konjenital kalp defekti

Pnömoni ve aspirasyon

Konjenital megakolon

Intestinal atrezi

Böbrek anomalileri

Omfalosel

Çocuklukta makrositer anemi

Sinir sistemi

Zihinsel yetersizlik

Spinal kord kompresyonu

Ensefalosel

Hemivertebra

Anal bölgede kuyruk

Genital hipoplazi

Servikal vertebra instabilitesi

İmmün yetmezlik

Sex reversal

\section{Kondrodisplazi punktata, Conradi-Hünermann tipi}

Osteogenezis imperfekta, hipofosfatazya, piknodizostozis, disosteosklerozis, osteopetrozis

Diastrofik displazi

Osteogenezis imperfekta, kampomelik displazi, kifomelik displazi, hipofosfatazya, metafizyel displazi Schmid tipi

Kampomelik displazi, diastrofik displazi

Ellis-van Creveld sendromu, kısa kosta polidaktili grubu

Diastrofik displazi

Kampomelik displazi

Diastrofik displazi

Kleidokraniyal displazi

Ellis-van Creveld sendromu, Jeune sendromu

Kampomelik displazi

Kıkırdak-saç hipoplazisi

Saldino-Mainzer displazisi

Jeune torasik displazi, kısa kosta polidaktili grubu, Saldino-Mainzer displazisi

Beemer-Langer sendromu

Kıkırdak-saç hipoplazisi

Dyggve-Melchior-Clausen displazisi, trikorinofalangeal displazi Tip II, Desbuquois displazisi Akondroplazi

Dissegmental displazi

Dissegmental displazi

Metatrofik displazi

Robinow sendromu

SED konjenita, akondroplazi, Larsen sendromu, SMMD

Schimke immünoosseöz displazi, kıkırdak saç hipoplazisi

Kampomelik displazi 
Tablo 6. İskelet displazilerinde başlangıç yaşı, klinik ve radyolojik bulgular ışığında ayıııı tanı

Temel klinik/radyolojik bulgu

Orantısız boy kısalığı; prenatal US'de kısa ekstremite, dar toraks, anormal kemik ossifikasyonu

Orantısız boy kısalığı; doğumda (prenatal başlangıçıı)

Orantısız boy kısalığı ( 1 ay -3 yaş)

Orantısız boy kısalığı (>3 yaş)

Kısa-kosta/polidaktili sendromları

Radyografide epifizlerde noktalanma (stippling)

Ekstremitelerin orta segmentinde kısalık (mezomeli)

Mezomeli ve kısa el ve ayakların olduğu durumlar (akromezomelik)

Kısa el ve ayaklar (akromelik) \pm kısa boy

Bükülmüş görünümlü uzun kemikler (klinik, radyolojik)

Birden fazla eklemde dislokasyon

Artmış kemik dansites

Kemik kırıkları

Kemikte destrüksiyon (osteolizis)

Erken yaşta artrit

Kemik çıkıntıları

İmmün yetmezlik semptomları

Depo hastalıkları semptomları
Ayırıcı tanıda neler düşünülmeli

Tanatoforik displazi, osteogenezis imperfekta Tip 2, akondrogenezis, kısa kostapolidaktili sendromları, platispondilik letal displaziler, hipofosfatazya

Akondroplazi, spondilo-epifizyel displazi (SED) konjenita, hipokondrogenezis, Kniest displazisi, diastrofik displazi, metatrofik displazi, Rolland-Desbuqoius displazi, opsismodisplazi

Hipokondroplazi, psödoakondroplazi, sponastrime displazi, metafizyel displaziler (Schmid, Jansen, McKusick), geleofizik displazi

Brakiyolmiya, SED tarda, spondilometafizyel displazi (Kozlowski), multipl epifizyel displazi, diskondroosteozis

SRP (Tip I/III, II, IV), Asfiksik torasik displazi (Jeune displazi), Ellis-van Creveld sendromu, Barnes sendromu

Zellweger sendromu, kondrodisplazi punktata (çeşitli etiyolojiler), CHILD sendromu

Diskondroosteozis, Robinow sendromu ve diğerleri

Akromezomelik displazi -Maroteux tipi, Grebe displazisi, Hunter-Thompson displazisi

Brakidaktili tipleri, akromikrik displazi, geleofizik displazi, akrodizostozis, trikorinofalangeal (TRP) displaziler

Kampomelik displazi, Cumming sendromu, Stüve-Wiedemann displazi, oto-palato-dijital sendrom Tip 2

Larsen sendromu, Desbuquois displazi, psödodiastrofik displazi, ateleosteogenezis Tip 3, Hunter-Thompson displazi

Osteopetrozis tipleri, piknodizostozis, diyafizyel displazi, disosteosklerozis, kraniyo-tübüler displaziler, endosteal hiperostozis

Osteogenezis imperfekta tipleri, hipofosfatazya

Osteolizis tipleri

Multipl epifizyel displazi, Stickler sendromu, progresif psödoromatoid displazi, SED konjenita, psödoakondroplazi

Multipl ekzostozis, metakondromatozis, TRP Tip 2

Schimke displazisi, Shwachman-Diamond sendromu, kıkırdak-saç hipoplazisi

Mukopolisakkaridozlar, mukolipidozlar

Tablo 7. İskelet displazisi araştırılırken yapılması önerilen "genetik iskelet taraması"

Anteroposterior ve lateral kafa grafisi

Anteroposterior ve lateral vertebra grafisi

Pelvis ve dört ekstremitenin anteroposterior grafisi

El ve ayak anteroposterior grafisi

Yan diz grafisi (multipl epifizyel displazi resesif tip şüphesi olması durumunda) 
Tablo 8. Epifizyel punktasyon ile ilişkili durumlar

\begin{tabular}{|c|c|c|}
\hline \multirow[t]{11}{*}{ Ekstrensik nedenler } & \multirow[t]{5}{*}{ Teratojenler } & Ethanol \\
\hline & & Warfarin \\
\hline & & Diphenylhydantoin \\
\hline & & Phenacetin intoksikasyonu \\
\hline & & Diğer Vitamin $\mathrm{K}$ antagonistleri \\
\hline & \multirow[t]{3}{*}{ İntrauterin enfeksiyonlar } & Rubella \\
\hline & & CMV \\
\hline & & Listeria \\
\hline & \multirow[t]{2}{*}{ Maternal hastalık } & SLE \\
\hline & & Vitamin K eksikliği \\
\hline & Postnatal enfeksiyonlar & Bakteriyal kondritis \\
\hline \multirow[t]{31}{*}{ İntrensek nedenler } & \multirow[t]{7}{*}{ Kromozom hastalıkları } & Trizomi 13 \\
\hline & & Trizomi 18 \\
\hline & & Trizomi 21 \\
\hline & & Trizomi 9 \\
\hline & & $\mathrm{X} ; \mathrm{Y}$ translokasyonu \\
\hline & & Triploidi \\
\hline & & del (Xp22.32) \\
\hline & \multirow[t]{2}{*}{ Endokrin hastalıklar } & Konjenital hipotiroidizm \\
\hline & & Hipopituiterizm (ön lob) \\
\hline & \multirow[t]{10}{*}{ Tek gen hastalıkları (metabolik hastalıklar) } & Peroksizomal hastalıklar \\
\hline & & Zellweger sendromu \\
\hline & & I cell hastalığı \\
\hline & & GM1 gangliozidozis \\
\hline & & Sialidozis \\
\hline & & Niemann-Pick hastalığı \\
\hline & & Mukopolisakkaridozis \\
\hline & & Smith-Lemni-Opitz sendromu \\
\hline & & Metakromatik lökodistrofi \\
\hline & & Vitamin K epoxide redüktaz eksikliği \\
\hline & \multirow[t]{12}{*}{ Diğer tek gen hastalıkları } & Akrodizostozis \\
\hline & & Acheria \\
\hline & & Adams-Oliver sendromu \\
\hline & & Kondrodisplazi punktata (çeşitli formları) \\
\hline & & Greenberg displazi \\
\hline & & Cerebro-Costa-Mandibular displazi \\
\hline & & CHILD sendromu \\
\hline & & De Barsy sendromu \\
\hline & & De Lange sendromu \\
\hline & & Keutel sendromu \\
\hline & & Pacman displazi \\
\hline & & İhtiyozis, hipogonadizm \\
\hline
\end{tabular}


Tablo 9. Servikal vertebra anomalileri ile birlikte olabilecek iskelet displazileri

\begin{tabular}{ll}
\hline Akondroplazi & SADDAN sendromu \\
Atelosteogenezis Tip III & Psödoakondrodosplazi \\
Brakiyolmia OD tip & Piknodizostozis \\
Kampomelik displazi & Frontometafizyel displazi \\
OSMED & Metafizyel kondrodisplazi \\
Kondrodisplazi punktata & Osteopetrozis \\
Desbuquois displazisi & Otopalatodijital sendrom \\
Progresif psödoromatoid displazi & Osteogenezis imperfekta \\
Spondiloepifizyel displaziler: SED konjenita, Kniest displazi & Spondilometafizyel displazi \\
Opsismodisplazi & SED tarda \\
Metatrofik displazi & Mukopolisakkaridoz \\
Multipl ekzostozis sendromu & Schneckenbecken displazi \\
Larsen sendromu & Hipofosfatazya \\
Diastrofik displazi & Dissegmental displazi
\end{tabular}

Tablo 10. İskelet displazilerinde önerilen tetkikler

\begin{tabular}{|c|c|}
\hline Öykü & Soyağacı analiziyle kişisel öykü ve aile öyküsü \\
\hline Fizik inceleme & $\begin{array}{l}\text { Antropometrik ölçümler: boy, ağırlık, baş çevresi, kulaç mesafesi, üst/alt segment oranı } \\
\text { Dismorfik bulgular } \\
\text { Sistemik muayene bulguları }\end{array}$ \\
\hline 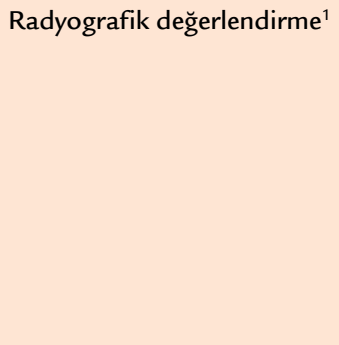 & $\begin{array}{l}\text { Kafatası ve tüm omurganın anteroposterior }(\mathrm{PA}) \text { ve lateral görüntüleri } \\
\text { Toraks PA görüntüsü } \\
\quad \text { (kosta tekniği ile) } \\
\text { Pelvis PA görüntüsü } \\
\text { Sol el PA görüntüsü } \\
\quad \text { (aynı zamanda kemik yaşı için) } \\
\text { Tüm diğer tübüler kemiklerin PA görüntüsü } \\
\quad \text { (eğer asimetriden şüphelenilmiyorsa, tek taraflı üst ve alt ekstremite ile sınırlandırılabilir) } \\
\text { Diz lateral görüntüsü } \\
\quad \text { (patella) }\end{array}$ \\
\hline \multicolumn{2}{|c|}{ Kıkırdak-kemik dokuların morfolojik değerlendirmesi } \\
\hline Işık mikroskopisi & $\begin{array}{l}\text { Örnekler: Femur, kosta (kostokondral eklem dahil), omurga, iliak krest, anormallik varsa diğer } \\
\text { kemiklerden alınabilir. } \\
\text { Tespit: \%10'luk nötral tamponlanmış formalin içinde yapılabilir. } \\
\text { İşlem: Alınacak örnek kemik, kıkırdak ve büyüme plağını içerecek şekilde uzunlamasına kesilir. }\end{array}$ \\
\hline Elektron mikroskopisi & $\begin{array}{l}\text { Örnekler: Işık mikroskopisi ile aynı. } \\
\text { Tespit: \%2,5 glutaraldehit, pH 7,4, fosfat, kakodilat veya Karnovsky tespiti ile tamponlanmış. } \\
\text { İşlem: Her örnekten yaklaşık } 1 \mathrm{~mm} \text { kalınlığında ve } 5-10 \mathrm{~mm} \text { uzunluğunda, ince dilimler (4-8 parça) alınır. }\end{array}$ \\
\hline Biyokimyasal çalışmalar & $\begin{array}{l}\text { İşlem, protein defektinin özelliğine bağlıdır. } \\
\text { Alınan cilt fibroblast örneğinde enzimatik çalışmalar yapılabilir. }\end{array}$ \\
\hline DNA çalışmaları & DNA dizi analizi ve tüm ekzom sekans analizi için 5-20 ml EDTA’lı kan (yenidoğanlarda 1-2 ml). \\
\hline
\end{tabular}

${ }^{1}$ Bir fetüs, yenidoğan veya küçük bir bebek için tüm vücut PA ve lateral filmleri yeterli olabilir. 
Tablo 11. İskeletin genetik hastalıklarının sınıflandırması - Nozoloji 2015 revizyonu

Grup/Hastalık adı

1. FGFR3 kondrodisplazi grubu

Tanatoforik displazi Tip 1 (TD1)

Tanatoforik displazi Tip 2 (TD2)

Severe achondroplasia with developmental delay and acanthosis nigricans (SADDAN)

Akondroplazi

Hipokondroplazi

Kamptodaktili, uzun boy, işitme kaybı sendromu (CATSHL)

Hipokondroplazi benzeri displazi(ler)

2. Kollajen Tip 2 grubu

Akondrogenezis Tip 2

Platispondilik displazi, Torrance tipi

Hipokondrogenezis

Spondiloepifizyel displazi konjenita (SEDC)

Spondiloepimetafizyel displazi (SEMD), Strudwick tipi

Kniest displazi

Spondiloperiferal displazi

Hafif SED erken başlangıçı ırthrozis

SED metatarsal kısalık ile beraber

Stickler sendromu Tip 1

3. Kollajen Tip 11 grubu

Stickler sendromu Tip 2

Marshall sendromu

Stickler sendromu Tip 3 (oküler olmayan)

Fibrokondrogenezis

Oto-spondilo-mega-epifizyel displazi (OSMED), resesif tip

Oto-spondilo-mega-epifizyel displazi (OSMED), dominant tip

(Weissenbancher-Zweymüller sendromu, Stickler sendromu tip 3)

4. Sülfasyon bozuklukları grubu

Akondrogenezis Tip 1b (ACG1B)

Atelosteogenezis Tip 2 (AO2)

Diastrofik displazi (DTD)

MED, resesif tipi (rMED; EDM4)

SEMD, PAPSS2 tipi

Brakiyolmia, resesif tipi

gPAPP tipi kondrodisplazi (Catel-Manzke benzeri sendrom dahil)

Konjenital eklem dislokasyonları ile beraber kondrodisplazi, CHST3 tipi (resesif Larsen sendromu)

Ehlers-Danlos sendromu, CHST14 tipi (muskuloskeletal varyant)

\section{Perlecan grubu}

Dissegmental displazi, Silverman-Handmaker tipi

Dissegmental displazi, Rolland-Desbuquois tipi

Schwartz-Jampel sendromu (miyotonik kondrodistrofi)
Kalıtım

Lokus/Gen

OD

FGFR3

OD

FGFR3

OD

FGFR3

OD

FGFR3

OD

FGFR3

OD

FGFR3

OD, $\mathrm{S}$

OD

COL2A1

OD

COL2A1

OD

COL2A1

OD

COL2A1

OD

COL2A1

OD

COL2A1

OD

COL2A1

OD

COL2A1

OD

COL2A1

OD

COL2A1

OD

COL11A1

OD

COL11A1

OD

COL11A2

OR, OD

OR

COL11A1, COL11A2

COL11A2

OD

COL11A2

OR

DTDST

OR

DTDST

OR

DTDST

OR

DTDST

OR

PAPSS2

OR

PAPSS2

OR

IMPAD1

OR

CHST3

OR

CHST14

OR

PLC

OR

PLC

OR

PLC 
Tablo 11 (devam). İskeletin genetik hastalıklarının sınıflandırması - Nozoloji 2015 revizyonu

Grup/hastalık adı

6. Aggrecan grubu

SED, Kimberley tipi

SEMD, Aggrecan tipi

Familial osteochondritis dissecans

7. Filamin grubu ve ilişkili hastalıklar

Frontometafizyel displazi

Melnick-Needles osteodisplasti

Otopalatodijital sendrom Tip 1

Otopalatodijital sendrom Tip 2

Terminal osseous dysplasia with pigmentary defects (TODPD)

Atelosteogenezis Tip 1 (AO1)

Atelosteogenezis Tip 3 (AO3)

Larsen sendromu, dominant

Spondilo-carpal-tarsal displazi

Frank-ter Haar sendromu

\section{TRPV4 grubu}

Metatrofik displazi

Spondiloepimetafizyel displazi, Maroteaux tipi

Spondiloepimetafizyel displazi, Kozlowski tipi

Brakiyolmia, dominant tip

Familial dijital arthropathy with brachydactyly

9. Belirgin iskelet tutulumunun olduğu siliopatiler

Kondroektodermal displazi (Ellis-van Creveld)

Kısa kosta polidaktili sendromu Tip 1/3 (Saldino-Noonan/Verma-Naumoff)

Asphyxiating thoracic dysplasia (ATD; Jeune)

SRPS Tip 2 (Majewski)

SRPS Tip 4 (Beemer)

SRPS Tip 5

Oral-fasyal-dijital sendrom Tip 4 (Mohr-Majewski)

Kraniyoektodermal displazi (Levin-Sensenbrenner) Tip 1, 2

Thoracolaryngopelvic dysplasia (Barnes)

10. Multipl epifizyel displazi (MED) ve psödoakondroplazi grubu

Psödoakondroplazi

MED Tip 1

MED Tip 2

MED Tip 3

MED Tip 5

MED Tip 6

MED diğer tipler

Stickler sendromu, resesif tip

Familial kalça displazisi (Beukes)

Multipl epifizyel displazi, mikrosefali, nistagmus (Lowry-Wood)
Kalıtım

Lokus/gen

$\begin{array}{lc}\text { OD } & \text { AGC1 } \\ \text { OR } & \text { AGC1 } \\ \text { OD } & \text { AGC1 } \\ \text { XLD } & \\ \text { XLD } & \text { FLNA } \\ \text { XLD } & \text { FLNA } \\ \text { XLD } & \text { FLNA } \\ \text { XLD } & \text { FLNA } \\ \text { OD } & \text { FLNA } \\ \text { OD } & \text { FLNB } \\ \text { OD } & \text { FLNB } \\ \text { OR } & \text { FLNB } \\ \text { OR } & \text { FLNB } \\ & \text { SH3PXD2B } \\ \text { OD } & \\ \text { OD } & \text { TRPV4 } \\ \text { OD } & \text { TRPV4 } \\ \text { OD } & \text { TRPV4 } \\ \text { OD } & \text { TRPV4 }\end{array}$

OR

EVC1, EVC2

OR

DYNC2H1, IFT80, WDR34

OR

DYNC2H1, IFT80, WDR34, TTC21B, WDR19, IFT172, IFT140

OR

DYNC2H1, NEK1

OR

OR

?

WDR35

OR

TCTN3

OR

OD

IFT122, WDR35, WDR19, IFT43

OD

COMP

OD

COMP

OD

COL9A2

OD

COL9A3

OD

MATN3

OD

COL9A1

?

OR

COL9A1

OD

$4 q 35$

OR 
Tablo 11 (devam). İskeletin genetik hastalıklarının sınıflandırması - Nozoloji 2015 revizyonu

\begin{tabular}{|c|c|c|}
\hline Grup/hastalık adı & Kalıtım & Lokus/gen \\
\hline \multicolumn{3}{|l|}{ 11. Metafizyel displazi } \\
\hline Metafizyel displazi, Schmid tipi & OD & COL10A1 \\
\hline Kıkırdak saç hipoplazisi & OR & RMRP \\
\hline Metafizyel displazi, kıkırdak saç hipoplazi benzeri, POP1 tipi & OR & POP1 \\
\hline Metafizyel displazi, Jansen tipi & OD & PTHR1 \\
\hline Eiken displazi & OR & PTHR1 \\
\hline $\begin{array}{l}\text { Metafizyel displazi, pankreatik yetmezlik, siklik nötropeni } \\
\text { (Shwachman-Bodian-Diamond sendromu) }\end{array}$ & OR & SBDS \\
\hline Metafizyel anadisplazi, Tip 1 & OD, OR & MMP13 \\
\hline Metafizyel anadisplazi, Tip 2 & OR & MMP9 \\
\hline Metafizyel displazi, Spahr tipi & OR & MMP13 \\
\hline Metafizyel displazi ve maksiller hipoplazi & OD & RUNX2 \\
\hline \multicolumn{3}{|l|}{ 12. Spondilometafizyel displazi (SMD) } \\
\hline Spondiloenkondrodisplazi (SPENCD) & OR & ACP5 \\
\hline Odontokondrodisplazi (ODCD) & OR & \\
\hline SMD, Sutcliffe tipi veya corner fractures tipi & OD & \\
\hline SMD ve cone-rod distrofi & OR & PYCT1A \\
\hline SMD ve retinal dejenerasyon, aksiyel tip & OR & \\
\hline \multicolumn{3}{|l|}{ 13. Spondilo-epi-(meta)-fizyel displaziler } \\
\hline Dyggve-Melchior-Clausen displazi (DMC) & OR & DYM, RAB33B \\
\hline Immuno-osseous dysplasia (Schimke) & OR & SMARCAL1 \\
\hline SED, Wolcott-Rallison tipi & OR & EIF2AK3 \\
\hline SEMD, Matrilin tipi & OR & MATN3 \\
\hline SEMD, short limb-abnormal calcification tipi & OR & DDR2 \\
\hline SED tarda, X-linked (SED-XL) & XLR & SEDL \\
\hline Spondylodysplastic Ehlers-Danlos sendromu & OR & SLC39A13 \\
\hline SPONASTRIME displazi & OR & \\
\hline Platyspondyly (brachyolmia) with Amelogenesis imperfecta & OR & \\
\hline CODAS sendromu & OR & LONP1 \\
\hline \multicolumn{3}{|l|}{ 14. Ağır spondilodisplastik displaziler } \\
\hline Akondrogenezis Tip 1A (ACG1A) & OR & TRIP11 \\
\hline Schneckenbecken displazi & OR & SLC35D1 \\
\hline Spondilometafizyel displazi, Sedaghatian tipi & OR & GPX4 \\
\hline Severe spondilometafizyel displazi (SMD Sedaghatian-like) & OR & SBDS \\
\hline Opsismodysplasia & OR & INPPL1 \\
\hline MAGMAS related skeletal dysplasia & OR & MAGMAS \\
\hline \multicolumn{3}{|l|}{ 15. Akromelik displaziler } \\
\hline Trikorinofalangeal displazi Tip $1 / 3$ & OD & TRPS1 \\
\hline Trikorinofalangeal displazi Tip 2 (Langer-Giedion) & OD & TRPS1, EXT1 \\
\hline Acrocapitofemoral displazi & OR & $\mathrm{IHH}$ \\
\hline Geleophysic displazi & OR & ADAMTSL2 \\
\hline Acromicric displazi & OD & FBN1 \\
\hline Weill-Marchesani & $\begin{array}{l}\text { OD } \\
\text { OR }\end{array}$ & $\begin{array}{l}\text { FBN1, ADAMTS10, ADAMTS17, } \\
\text { LTBP2 }\end{array}$ \\
\hline Myhre displazi & OD & SMAD4 \\
\hline Acrodysostosis & OD & PDE4D, PRKAR1A \\
\hline Angel-shaped phalango-epiphyseal dysplasia (ASPED) & OD & \\
\hline Albright hereditary osteodystrophy & OD & GNAS \\
\hline
\end{tabular}


Tablo 11 (devam). İskeletin genetik hastalıklarının sınıflandırması - Nozoloji 2015 revizyonu

Grup/hastalık adı

16. Akromezomelik displaziler

Akromezomelik displazi Maroteaux tipi (AMDM)

Grebe displazi

Fibular hipoplazi ve kompleks brakidaktili (Du Pan)

Akromezomelik displazi, genital anomaliler ile beraber

Akromezomelik displazi, Osebold-Remondini tipi

17. Mesomelik ve rizomesomelik displaziler

Dyschondrosteosis (Leri-Weill)

Langer tipi (homozygous dyschondrosteosis)

Omodisplazi

Omodisplazi dominant tip

Robinow sendrom, resesif tip

Robinow sendrom, dominant tip

Mezomelik displazi, Kantaputra tipi

Mezomelik displazi, Nievergelt tipi

Mezomelik displazi, Kozlowski-Reardon tipi

Mesomelic dysplasia with acral synostoses

(Verloes-David-Pfeiffer tipi)

Mezomelik displazi, Savarirayan tipi (triangular tibia-fibular aplasia)

18. Kampomelik displazi ve ilişkili hastalıklar

Kampomelik displazi

Stuve-Wiedemann displazi

Kifomelik displazi, pek çok formu

19. Slender kemik displazisi grubu

$3 \mathrm{M}$ sendromu

Kenny-Caffey displazi

Kenny-Caffey displazi

Osteocraniostenosis

Microsephalic osteodysplastic primordial dwarfism Tip 1/3 (MOPD1)

Microsephalic osteodysplastic primordial dwarfism Tip 2

(MOPD2; Majewski tipi)

IMAGE sendromu (intrauterine growth retardation, metafizyel displazi, adrenal hipoplazi, genital anomaliler)

Hallermann-Streiff sendromu

20. Multipl eklem dislokasyonları ile karakterize displaziler

Desbuquois displazi

(with accessory ossification centre in digit 2)

Desbuquois dysplasia with short metacarpals and elongated phalanges (Kim tipi)

Desbuquois displazi Tip 2

Psödodiastrofik displazi

SEMD with joint laxity (SEMD-JL) leptodactylic veya Hall tipi

SEMD with joint laxity (SEMD-JL) Beighton tipi
OR

OR

Kalıtım

Lokus/gen

$\begin{array}{lc}\text { OR } & \text { NPR2 } \\ \text { OR } & \text { GDF5 } \\ \text { OR } & \text { GDF5 } \\ \text { OR } & \text { BMPR1B } \\ \text { OD } & \end{array}$

$\begin{array}{cc}\text { PsödoOD } & \text { SHOX } \\ \text { PsödoOR } & \text { SHOX } \\ \text { OR } & \text { GPC6 } \\ \text { OD } & \text { FZD2 } \\ \text { OR } & \text { ROR2 } \\ \text { OD } & \text { WNT5A, DVL1 } \\ \text { OD } & \\ \text { OD } & \\ \text { OR } & \\ \text { OD } & \text { SULF1, SLC5A1 } \\ \text { SP } & 6 \mathrm{~T} 22.3 \text { delesyonu }\end{array}$

OD

SOX9

OR

LIFR

OD

OD

OR

OR

CUL7, OBSL1,, CCDC8

TBCE

FAM111A

FAM111A

RNU4ATAC

PCNT2

OD

CDKN1C

OR

OR

CANT1

OR

CANT1

OR

XYLT1

OR

OD

KIF22

OR 
Tablo 11 (devam). İskeletin genetik hastalıklarının sınıflandırması - Nozoloji 2015 revizyonu

Grup/hastalık adı
21. Kondrodisplazi punktata (CDP) grubu
CDP, X-linked dominant, Conradi-Hünermann tipi (CDPX2)
CDP, X-linked recessive, brachytelephalangic tip (CDPX1)
CHILD (congenital hemidysplasia, ichthyosis, limb defects)
Keutel sendromu
Greenberg displazi
Rizomelik CDP Tip 1
Rizomelik CDP Tip 2
Rizomelik CDP Tip 3
CDP tibial-metakarpal tip
Astley-Kendall displazi

Kalıtım

Lokus/gen

22. Neonatal osteosklerotik displaziler

Bloomstrand displazi

OR

PTHR1

Desmosterolosis

$\begin{array}{cc}\text { XLD } & \text { EBP } \\ \text { XLR } & \text { ARSE } \\ \text { XLD } & \text { NSDHL } \\ \text { OR } & \text { MGP } \\ \text { OR } & \text { LBR } \\ \text { OR } & \text { PEX7 } \\ \text { OR } & \text { DHPAT } \\ \text { OR } & \text { AGPS }\end{array}$

Caffey hastalığı

OR

DHCR24

Caffey displazi

OD

COL1A1

Raine displazi

OR

OR

FAM20C

23. Osteopetrozis ve ilişkili hastalıklar

Osteopetrozis ağır neonatal veya infantil form (OPTB1)

OR

TCIRG1

Osteopetrozis ağır neonatal veya infantil form (OPTB4)

OR

CLCN7

Osteopetrozis ağır neonatal veya infantil form (OPTB8)

OR

SNX10

Osteopetrozis infantil form, sinir sistemi tutulumu (OPTB5)

OR

OSTM1

Osteopetrozis, ara form, osteoklasttan-fakir (OPTB2)

OR

RANKL

Osteopetrozis, infantil form, osteoklasttan-fakir, Ig eksikliği (OPTB7)

OR

RANK

Osteopetrozis, ara form (OPTB6)

OR

PLEKHM1

Osteopetrozis, ara form (OPTA2)

OR

CLCN7

Osteopetrozis ve renal tübüler asidoz (OPTB3)

OR

CA2

Osteopetrozis geç başlangıçı form Tip 1 (OPTA1)

OD

LRP5

Osteopetrozis geç başlangıçı form Tip 2 (OPTA2)

OD

CLCN7

Osteopetrozis, ektodermal displazi ve immün yetmezlik (OLEDAID)

$\mathrm{XL}$

Osteopetrozis, defektif lökosit adhezyonu orta form (LAD3)

IKBKG

Osteopetrozis, defektif lökosit adhezyonu orta form

FERMT3

Piknodizostozis

RASGRP2

Osteopoikilosis

CTSK

Melorheostosis with osteopoikilosis

LEMD3

Osteopathia striata with cranial sclerosis

LEMD3

Melorheostosis

WTX

Disosteosklerozis

SLC29A3 
Tablo 11 (devam). İskeletin genetik hastalıklarının sınıflandırması - Nozoloji 2015 revizyonu

\begin{tabular}{|c|c|c|}
\hline Grup/hastalık adı & Kalıtım & Lokus/gen \\
\hline \multicolumn{3}{|l|}{ 24. Diğer sklerozan kemik hastalıkları } \\
\hline Kraniyometafizyel displazi, OD tip & OD & ANKH \\
\hline Diyafizyel displazi Camurati-Engelmann & OD & TGFB1 \\
\hline Hematodiyafizyel displazi Ghosal & OR & TBXAS1 \\
\hline Hypertrophic osteoarthropathy & OR & HPGD \\
\hline $\begin{array}{l}\text { Pachydermoperiostosis } \\
\text { (hypertrophic osteoarthropathy, primary, otozomal dominant) }\end{array}$ & OD & \\
\hline Oculo-dento-osseous displazi (ODOD) hafif tip & OD & GJA1 \\
\hline Oculo-dento-osseous displazi (ODOD) ağır tip & OR & GJA1 \\
\hline Osteoectasia with hyperphosphatasia (juvenile Paget disease) & OR & OPG \\
\hline Sclerosteosis & OD, OR & SOST, LPR4 \\
\hline Endosteal hyperostosis, van Buchem tipi & OR & SOST \\
\hline Trichodentoosseous displazi & OD & DLX3 \\
\hline Kraniyometafizyel displazi, OR tipi & OR & GJA1 \\
\hline Diaphyseal medullary stenosis with malignant fibrous histiocytoma & OD & \\
\hline Kraniyodiyafizyel displazi & OD & SOST \\
\hline Kraniyometadiyafizyel displazi, Wormian bone type & OR & \\
\hline Endosteal sclerosis with cerebellar hypoplasia & OR & \\
\hline Lenz-Majewski hiperostotik displazi & SP & PTDSS1 \\
\hline Metafizyel displazi, Braun-Tinschert tipi & OD & \\
\hline Pyle hastalığı & OR & \\
\hline \multicolumn{3}{|l|}{ 25. Osteogenezis imperfekta ve azalmış kemik dansitesi grubu } \\
\hline Osteogenezis imperfekta, non-deforming form (OI Tip 1) & OD & COL1A1, COL1A2 \\
\hline Osteogenezis imperfekta, perinatal lethal form (OI Tip 2) & OR, OD & $\begin{array}{l}\text { COL1A1, COL1A2, } \\
\text { CRTAP, LEPRE, PPIB }\end{array}$ \\
\hline Osteogenezis imperfekta, progressively-deforming form (OI Tip 3) & OD, OR & $\begin{array}{l}\text { COL1A1, COL1A2, CRTAP, LEPRE1, } \\
\text { PPIB, SERPINH1, BMP1, FKBP10, } \\
\text { PLOD2, SERPINF1, SP7, WNT1, } \\
\text { TMEM38B, CREB3L1, SEC24D }\end{array}$ \\
\hline Osteogenezis imperfekta, moderate form (OI Tip 4) & OD, OR & $\begin{array}{l}\text { COL1A1, COL1A2, CRTAP, PPIB, } \\
\text { FKBP10, SERPINF1, WNT1, SP7 }\end{array}$ \\
\hline $\begin{array}{l}\text { Osteogenezis imperfekta, interosseöz membranların kalsifikasyonu ve/veya } \\
\text { hipertrofik kallus ile karakterize (OI Tip 5) }\end{array}$ & OD & IFITM5 \\
\hline X’e bağlı osteoporoz & $\mathrm{XL}$ & PLS3 \\
\hline Bruck sendromu Tip 1 & OR & FKBP10 \\
\hline Bruck sendromu Tip 2 & OR & PLOD2 \\
\hline Osteoporozis-psödoglioma sendromu & OR & LRP5 \\
\hline LRP5 primer osteoporoz & OD & LRP5 \\
\hline Calvarial doughnut lesions with bone fragility & OD & \\
\hline İdiyopatik juvenil osteoporozis & SP & \\
\hline Cole-Carpenter displazisi & OD & $\mathrm{P} 4 \mathrm{HB}$ \\
\hline Spondilo-oküler displazi & OR & XYLT2 \\
\hline Osteopenia with radiolucent lesions of the mandible & OD & \\
\hline Ehlers-Danlos sendromu, progeroid formu & OR & B4GALT7 \\
\hline Geroderma osteodysplasticum & OR & GORAB \\
\hline Cutis laxa, autosomal recessive form, Tip 2B (ARCL2B) & OR & PYCR1 \\
\hline $\begin{array}{l}\text { Cutis laxa, autosomal recessive form, Tip 2A (ARCL2A) } \\
\text { (Wrinkly skin syndrome) }\end{array}$ & OR & ATP6VOA2 \\
\hline Singleton-Merten dysplasia & OD & \\
\hline
\end{tabular}


Tablo 11 (devam). İskeletin genetik hastalıklarının sınıflandırması - Nozoloji 2015 revizyonu

\begin{tabular}{lcr}
\hline Grup/hastalık adı & Kalıtım & Lokus/gen \\
\hline 26. Anormal mineralizasyon grubu & & ALPL \\
Hipofosfatazya, perinatal ölümcül, infantil ve juvenil formları & OR & ALPL \\
Hipofosfatazya, juvenil ve erişkin formları & OD & PHEX \\
Hipofosfatemik rikets, XLD & XLD & FGF23 \\
Hipofosfatemik rikets, OD & OD & DMP1 \\
Hipofosfatemik rikets, OR, Tip 1 (ARHR1) & OR & ENPP1 \\
Hipofosfatemik rikets, OR, Tip 2 (ARHR2) & OR & CICN5 \\
Hipofosfatemik rikets ve hiperkalsiüri, XLR & XLR & SLC34A3 \\
Hipofosfatemik rikets ve hiperkalsiüri, OR (HHRH) & OR & CASR \\
Neonatal hiperparatiroidizm, ağır formu & OR & OD \\
Ailesel hipokalsiürik hiperkalsemi ve geçici neonatal hiperparatiroidizm & OD & CASR \\
Calcium pyrophosphate depo hastalığı (familial chondrocalcisnosis) Tip 2 & ANKH
\end{tabular}

27. İskelet tutulumunun olduğu lizozomal depo hastalıkları (Dizostozis multipleks grubu)

Mukopolisakkaridozis Tip 1H/1S (Hurler, Hurler-Scheie, Scheie)

OR

IDA

Mukopolisakkaridozis Tip 2 (Hunter)

XLR

IDS

Mukopolisakkaridozis Tip 3A (Sanfilippo A)

OR

HSS

Mukopolisakkaridozis Tip 3B (Sanfilippo B)

OR

NAGLU

Mukopolisakkaridozis Tip 3C (Sanfilippo C)

OR

HSGNAT

Mukopolisakkaridozis Tip 3D (Sanfilippo D)

OR

GNS

Mukopolisakkaridozis Tip 4A (Morquio A)

OR

GALNS

Mukopolisakkaridozis Tip 4B (Morquio B)

OR

GLB1

Mukopolisakkaridozis Tip 6 (Maroteaux-Lamy)

OR

ARSB

Mukopolisakkaridozis Tip 7 (Sly)

OR

GUSB

Fucosidosis

OR

FUCA

Alpha-Mannosidosis

OR

MANA

Beta-Mannosidosis

OR

MANB

Aspartylglucosaminuria

OR

AGA

GMI Gangliosidosis, pek çok formu

GLB1

Sialidosis, pek çok formu

OR

NEU1

Sialic acid depo hastalığı (SIASD)

OR

SLC17A5

Galactosialidosis, pek çok formu

OR

PPGB

Multipl sülfataz eksikliği

SUMF1

Mukolipidozis II (I-cell disease), alpha/beta tipi

GNPTAB

Mukolipidozis III (pseudo-Hurler polydystrophy), alpha/beta tipi

GNPTAB

Mukolipidozis III (pseudo-Hurler polydystrophy), gamma tipi

GNPTG

28. Osteolizis grubu

Familial expansile osteolisis

OD

RANK

Mandibuloakral displazi Tip A

OD

LMNA

Mandibuloakral displazi Tip B

OR

ZMPSTE24

Progeria, Hutchinson-Gilford tipi

OD

LMNA

Torg-Winchester sendromu

OR

MMP2

Hajdu-Cheney sendromu

OD

$\mathrm{NOTCH} 2$

Multisentrik karpal-tarsal osteolizis

OD

MAFB 
Tablo 11 (devam). İskeletin genetik hastalıklarının sınıflandırması - Nozoloji 2015 revizyonu

Grup/hastalık adı
29. İskelet bileşenlerinin gelişiminde organizasyon bozukluğu

Multiple cartilaginous exostoses 1

Kalıtım

Lokus/gen

Multiple cartilaginous exostoses 2

OD

EXT1

Multiple cartilaginous exostoses 3

OD

EXT2

Cherubism

OD

Fibröz displazi, poliostotik form (McCune-Albright)

OD

SH3BP2

Progressive osseos heteroplasia

SP

GNAS

Gnathodiaphyseal displasia

OD

GNAS

Metakondromatozis

OD

TMEM16E

Osteoglophonic displasia

OD

PTPN11

Fibrodysplasia ossificans progressiva (FOP)

OD

FGFR1

Nörofibromatozis Tip 1 (NF1)

OD, SP

ACVR1

Karpotarsal osteokondromatozis

OD

NF1

Cherubism with gingival fibromatosis (Ramon syndrome)

OD

Dysplasia epiphysealis hemimelica (Trevor)

OR

$\mathrm{SP}$

Lipomembraneous osteodystrophy with leukoencephalopathy (presenile dementia with bone cysts; Nasu-Hakola)

OR

TREM2, TYROBP

Enchondromatosis (Ollier) and enchondromatosis with hemangiomata (Maffucci)

$\mathrm{SP}$

IDH1, IDH2

Metaphyseal chondromatosis with D-2-hydroxyglutaric aciduria

$S P, O D$

Genochondromatosis

Gorham-Stout

30. İskelet tutulumunun olduğu aşırı büyüme sendromları

Weaver sendromu

SP/OD

$\mathrm{EZH} 2$

Sotos sendromu

OD

NSD1

Sotos benzeri sendrom

OD

SETD2

Marshall-Smith sendromu

SP

NFIX

Proteus sendromu

$\mathrm{SP}$

AKT1

CLOVES

SP

PIK3CA

Marfan sendromu

OD

FBN1

Konjenital kontraktural araknodaktili

OD

FBN2

Loeys-Dietz sendromu Tip 1A, 1B, 2A, 2B, 3,4

OD

$2 q 37$ translokasyonu ile beraber aşırı büyüme sendromu

Makrodaktili ve NPR2 fonksiyon kazanımı mutasyonu ile beraber aşııı

TGFBR1, TGFBR2, SMAD3, TGFB2

büyüme sendromu

SP

NPPC

NPR2

İskelet displazi ile beraber aşırı büyüme sendromu

31. Genetik inflamatuvar/rheumatoid-like osteoarthropathies

Progressive pseudorheumatoid displasia

(PPRD; SED with progressive arthropathy)

Chronic infantile neurologic cutaneous articular syndrome

(CINCA) / neonatal onset multisystem inflammatory disease (NOMID)

Sterile multifocal osteomyelitis, periostitis ve pustulosis

(CINCA/NOMID-like)

Chronic recurrent multifocal osteomyelitis with congenital dyserythropoietic anemia (CRMO with CDA; Majeed sendromu)

Hyperostosis/hyperphosphatemia syndrome

OR

WISP3

OD

CIAS1

Hiyalin fibromatozis sendromu

OR

IL1RN

OR

LPIN2

OR

GALNT3

OR

ANTXR2 
Tablo 11 (devam). İskeletin genetik hastalıklarının sınıflandırması - Nozoloji 2015 revizyonu

\begin{tabular}{|c|c|c|}
\hline Grup/hastalık adı & Kalıtım & Lokus/gen \\
\hline \multicolumn{3}{|l|}{ 32. Kleidokraniyal displazi ve ilişkili hastalıklar } \\
\hline Kleidokraniyal displazi & OD & RUNX2 \\
\hline $\begin{array}{l}\text { CDAGS sendromu (craniosynostosis, delayed fontanel closure, parietal foramina, } \\
\text { imperforate anus, genital anomalies, skin eruption) }\end{array}$ & OR & \\
\hline Yunis-Varon displazisi & OR & FIG4 \\
\hline Parietal foramina (izole) & OD & ALX4, MSX2 \\
\hline \multicolumn{3}{|l|}{ 33. Kraniyosinostozis sendromları } \\
\hline Pfeiffer sendromu (FGFR1-ilişkili) & OD & FGFR1, FGFR2 \\
\hline Apert sendromu & OD & FGFR2 \\
\hline Cutis gyrata ile beraber kraniyosinostozis (Beare-Stevenson) & OD & FGFR2 \\
\hline Crouzon sendromu & OD & FGFR2 \\
\hline Bent-bone displasia & OD & FGFR2 \\
\hline $\begin{array}{l}\text { Acanthosis nigricans ile beraber Crouzon benzeri kraniyosinostozis } \\
\text { (Crouzonodermoskeletal syndrome) }\end{array}$ & OD & FGFR3 \\
\hline Kraniyosinostozis, Muenke tipi & OD & FGFR3 \\
\hline Antley-Bixler sendromu & OR & POR \\
\hline Kraniyosinostozis Boston tipi & OD & MSX2 \\
\hline Saethre-Chotzen sendromu & OD & TWIST \\
\hline Shprintzen-Goldberg sendromu & OD & SKI \\
\hline Baller-Gerold sendromu & OR & RECQL4 \\
\hline Carpenter sendromu & OR & RAB23 MEGF8 \\
\hline Koronal kraniyosinostozis & OD & TCF12 \\
\hline Komplike kraniyosinostozis & OD & ERF \\
\hline
\end{tabular}

34. Kraniyofasyal tutulumun belirgin olduğu dizostozisler

Mandibulo-facial dysostosis (Treacher Collins, Franceschetti-Klein)

Oral-fasyal-dijital sendrom Tip I (OFD1)

Weyers akrofasyal (akrodental) dizostozis

OD, OD, OR
XLR
OD
OR
XLD
OR
OR
OR
SP/OD
OR
OD/OR
OR
OD

TCOF1, POLR1D, POLR1C
CXORF5
EVC1, EVC2
ICK
EFNB1
ALX3
ALX4
ALX1

Frontonazal displazi, Tip

Hemifasyal mikrozomi

Miller sendromu (postaxial acrofacial dysostosis)

Akrofasyal dizostozis, Nager tipi

Akrofasyal dizostozis, Rodriguez tipi

Mandibulofacial dysostosis with microcephaly

35. Vertebra \pm kosta tutulumunun belirgin olduğu dizostozisler

Currarino triadı

OD

$\mathrm{DHODH}$

Spondilokostal dizostozis Tip 1, Tip 2, Tip 3, Tip 4

OR

Spondilokostal dizostozis Tip 5

OD

Spondilotorasik dizostozis

Penetransın değişken olduğu vertebral segmentasyon defekti

OR

OD

SF3B4

(konjenital skolyoz)

Laringeal malformasyon ile beraber Klippel-Feil anomalisi

OD

OR

Serebro-kosta-mandibular sendrom (rib gap sendromu)

OD

EFTUD2

Serebro-kosta-mandibular benzeri sendrom ile beraber vertebral defekt

Diaphanospondylodysostosis

OR

HLXB9

Spondilo-megaepifizyel-metafizyel displazi (SMMD)

OR

OR

DLL3, MESP2, LFNG, HES7
TBX6
MESP2
MESP2, HES7
GDF6, GDF3, MEOX1
SNRPB
COG1
BMPER
NKX3-2


Tablo 11 (devam). İskeletin genetik hastalıklarının sınıflandırması - Nozoloji 2015 revizyonu

Grup/hastalık adı
36. Patellar dizostozisler
İskiopatellar displazi (küçük patella sendromu)
Nail-patella sendromu
Genitopatellar sendrom
Kulak-patella-kısa boy sendromu (Meier-Gorlin)

37. Brakidaktili (iskelet dışı bulguların olmadığı grup)

Brakidaktili Tip A1

Brakidaktili Tip A1

Brakidaktili Tip A2

Brakidaktili Tip A2

Brakidaktili Tip A2

Brakidaktili Tip B

Brakidaktili Tip B2

Brakidaktili Tip C

Brakidaktili Tip D

Brakidaktili Tip E

Brakidaktili Tip E

Brakidaktili ve anonychia (Cooks sendromu)

38. Brakidaktili (iskelet dışı bulguların olduğu grup)

Brakidaktili-mental retardasyon sendromu

Hiperfosfotazya, mental retardasyon, brakitelefalanji, ayırt edici yüz

Brakidaktili-hipertansiyon sendromu (Bilginturan)

Mikrosefali-okulo-dijito-esohageal-duodenal sendrom (Feingold sendromu)

El-ayak-genital sendrom

Rubinstein-Taybi sendromu

Rubinstein-Taybi sendromu

Brakidaktili, Temtamy tipi

Christian tipi brakidaktili

Coffin-Siris sendromu 1

Adams-Oliver

Catel-Manzke sendromu

39. Limb hipoplazi-redüksiyon defektleri

Ulnar-mammary sendromu

de Lange sendromu

Fanconi anemisi

Thrombocytopenia-absent radius (TAR)

Thrombocythemia with distal limb defects

Holt-Oram sendromu

Okihiro sendromu (Duane-radial ray anomaly)

Cousin sendromu

Roberts sendromu

Split-hand-foot malformation with long bone deficiency (SHFLD3)

Tibial hemimelia
Kalıtım

Lokus/gen

\begin{tabular}{|c|c|}
\hline OD & TBX4 \\
\hline OD & LMX1B \\
\hline OR? & KAT6B \\
\hline OR & ORC1, ORC4, ORC6, CDT1, CDC6 \\
\hline OD & $\mathrm{IHH}$ \\
\hline \multicolumn{2}{|l|}{ OD } \\
\hline OD & BMPR1B \\
\hline OD & BMP2 \\
\hline OD & GDF5 \\
\hline OD & ROR2 \\
\hline OD & NOG \\
\hline OD, OR & GDF5 \\
\hline OD & HOXD13 \\
\hline OD & PTHLH \\
\hline OD & HOXD13 \\
\hline OD & SOX9 \\
\hline OD & HDAC4 \\
\hline OR & PIGV \\
\hline OD & PDE3A \\
\hline OD & MYCN \\
\hline OD & HOXA13 \\
\hline OD & CREBBP \\
\hline OD & EP300 \\
\hline OR & CHSY1 \\
\hline \multicolumn{2}{|l|}{ OD } \\
\hline \multicolumn{2}{|l|}{ OR } \\
\hline OD, OR & ARHGAP31, DOCK6, RBPJ, EOGT \\
\hline OR & TGDS \\
\hline OD & TBX3 \\
\hline $\begin{array}{l}\text { OD } \\
X L\end{array}$ & $\begin{array}{c}\text { NIPBL, SMC1A, SMC3, RAD21 } \\
\text { HDAC8 }\end{array}$ \\
\hline OR & (pek çok) \\
\hline OR & RBM8A \\
\hline OD & THPO \\
\hline OD & TBX5 \\
\hline OD & SALL4 \\
\hline OR & TBX15 \\
\hline OR & $\mathrm{ESCO} 2$ \\
\hline OD & BHLHA9 \\
\hline
\end{tabular}


Tablo 11 (devam). İskeletin genetik hastalıklarının sınıflandırması - Nozoloji 2015 revizyonu

\begin{tabular}{|c|c|c|}
\hline Grup/hastalık adı & Kalıtım & Lokus/gen \\
\hline Tibial hemimelia-polysyndactyly-triphalangeal thumb & OD & SHHZRS \\
\hline Acheiropodia & OR & LMBR1 \\
\hline Tetra-amelia & OR & WNT3 \\
\hline Terminal transvers defekti & $?$ & \\
\hline Al-Awadi Raas-Rothschild limb-pelvis hypoplasia-aplasia & OR & WNT7A \\
\hline Fuhrmann sendromu & OR & WNT7A \\
\hline RAPADILINO sendromu & OR & RECQL4 \\
\hline \multicolumn{3}{|l|}{ Poland } \\
\hline Femoral hypoplasia-unusual face sendromu (FHUFS) & SP/OD? & \\
\hline Femur-fibula-ulna sendromu (FFU) & SP? & \\
\hline Hanhart sendromu (hypoglossia-hypodactylia) & OD & \\
\hline Gollop-Wolfgang & OD & BHLHA9 \\
\hline Skapulo-iliak displazi (Kosenow) & OD & \\
\hline \multicolumn{3}{|l|}{ 40. Ektrodaktili \pm diğer bulgular } \\
\hline Ankyloblepharon-ectodermal dysplasia-cleft lip/palate (AEC) & OD & P63 \\
\hline Ectrodactyly-ectodermal dysplasia cleft-palate syndrome Tip 3 (EEC3) & OD & P63 \\
\hline Ectrodactyly-ectodermal dysplasia cleft-palate syndrome Tip 1 (EEC1) & OD & \\
\hline Ectrodactyly-ectodermal dysplasia-macular dystrophy syndrome (EEM) & OR & $\mathrm{CDH} 3$ \\
\hline Limb-mammary syndrome (ADULT sendromu da içerir) & OD & P63 \\
\hline Split hand-foot malformasyonu, izole form, Tip 4 (SHFM4) & OD & P63 \\
\hline Split hand-foot malformasyonu, izole form, Tip 1 (SHFM1) & OD & $\begin{array}{l}\text { DLX5 } \\
\text { DLX6 }\end{array}$ \\
\hline Split hand-foot malformasyonu, izole form, Tip 3 (SHFM3) & OD & $10 q$ \\
\hline Split hand-foot malformasyonu, izole form, Tip 5 (SHFM5) & OR & WNT10B \\
\hline Hartsfield sendromu & OD & FGFR1 \\
\hline \multicolumn{3}{|l|}{ 41. Polidaktili-Sindaktili-Triphalangism grubu } \\
\hline Preaksiyel polidaktili Tip 1 & OD & SHH-ZRS \\
\hline Postaksiyel polidaktili Tip A & OD & GLI3 \\
\hline Postaksiyel polidaktili Tip B & Kompleks & \\
\hline Triphalangeal thumb - polidaktili sendromu & OD & SHH-ZRS \\
\hline Preaksiyel polidaktili Tip 3 & OD & $?$ \\
\hline Preaksiyel polidaktili Tip 4 & OD & GLI3 \\
\hline Greig sefalopolisindaktili sendromu & OD & GLI3 \\
\hline Pallister-Hall sendromu & OD & GLI3 \\
\hline Sinpolidaktili (komplike, fibulin1 ilişkili) & OD & FBLN1 \\
\hline Sinpolidaktili & OD & HOXD13 \\
\hline Townes-Brocks sendromu (renal-ear-anal-radial sendrom) & OD & SALL1 \\
\hline Lacrimo-auriculo-dento-digital syndrome (LADD) & OD & FGFR2 \\
\hline Lacrimo-auriculo-dento-digital syndrome (LADD) & OD & FGFR3 \\
\hline Lacrimo-auriculo-dento-digital syndrome (LADD) & OD & FGF10 \\
\hline Acrocallosal syndrome & OR & KIF7 \\
\hline Acro-pectoral syndrome & OD & \\
\hline Acro-pectoro-vertebral dysplasia ( $\mathrm{F}$ sendromu) & OD & WNT6 \\
\hline El ve ayakların ayna hayali polidaktilisi (Laurin-Sandrow sendromu) & OD & SHH-ZRS \\
\hline
\end{tabular}


Tablo 11 (devam). İskeletin genetik hastalıklarının sınıflandırması - Nozoloji 2015 revizyonu

\begin{tabular}{|c|c|c|}
\hline Grup/hastalık adı & Kalıtım & Lokus/gen \\
\hline Cenani-Lenz sindaktili & OR & LRP4 \\
\hline Cenani-Lenz benzeri sindaktili & $\mathrm{SP},(\mathrm{OD} ?)$ & GREM1, FMN1 \\
\hline Sindaktili, Malik-Perçin tipi & OD & BHLHA9 \\
\hline $\begin{array}{l}\text { STAR sendromu (ayak parmaklarında sindaktili, telekantus, ano-renal } \\
\text { malformasyonlar) }\end{array}$ & $X L$ & FAM58A \\
\hline Sindaktili Lueken tipi & OD & IHH \\
\hline Okülodentodijital displazi, sindaktili Tip 3 & OD & GJA1 \\
\hline Sindaktili Haas tipi & OD & SHH-ZRS \\
\hline Metakarpal ve metatarsal füzyonu ile beraber sindaktili & OD & HOXD13 \\
\hline Metakarpal 4-5 füzyonu sendromu & $X L$ & FGF16 \\
\hline Kraniyosinostozis ile beraber sindaktili (Philadelphia tipi) & OD & $\mathrm{IHH}$ \\
\hline Mikrosefali ve zihinsel yetersizlik ile beraber sindaktili (Filippi sendromu) & OR & CKAP2L \\
\hline Meckel sendromu Tip 1-6 & OR & $\begin{array}{l}\text { MKS1, TMEM216, TMEM67, } \\
\text { CEP290, RPGRIP1L, CC2D2A }\end{array}$ \\
\hline \multicolumn{3}{|l|}{ 42. Eklem oluşumundaki defektler ve sinostozlar } \\
\hline Multipl sinostoz sendromu Tip 3 & OD & FGF9 \\
\hline Proximal symphalangism Tip 1 & OD & NOG \\
\hline Proximal symphalangism Tip 2 & OD & GDF5 \\
\hline Radyo-ulnar sinostoz ve amegakariyositik trombositopeni & OD & HOXA11 \\
\hline Liebenberg sendromu & OD & PITX1 \\
\hline Konjenital pes ekinovarus & OD & PITX1 \\
\hline
\end{tabular}

Tablo 12. İskeletin genetik hastalıklarının moleküler-patogenetik sınıflandırması

\begin{tabular}{cl}
\hline Grup & Etiyoloji \\
\hline 1 & Ekstrasellüler yapısal proteinlerde defektler \\
2 & $\begin{array}{l}\text { Metabolik yolaklarda defektler } \\
\text { (enzim, iyon kanalları ve taşıyıcı moleküller) }\end{array}$
\end{tabular}

3 Makromoleküllerin katlanması, işlenmesi, taşınması ve yıkımında defektler

4 Hormon ve sinyal iletim mekanizmalarında defektler

$5 \quad$ Nükleer protein ve transkripsiyon faktörlerinde defektler

6 RNA işlem mekanizmaları ve metabolizmasında defektler

7 Sitoskeletal proteinlerde defektler ilgili genler

COL1A1 (MIM 120150), COL1A2 (MIM 120160),

COL2A1 (MIM 120140), COL9A1 (MIM 120210),

COL9A2 (MIM 120260), COL9A3 (MIM 120270), COL10A1 (MIM 120110), COMP (MIM 600310), MATN3 (MIM 602109), perlecan (MIM 142461)

TNSALP (MIM171760), ANKH (MIM 605145), DTDST/SLC26A2 (MIM606718), PAPSS2 (MIM 603005), ARSE (MIM 300180), CLC7 (MIM 602727), PEX7 (MIM 601757), CHST3 (MIM 603799)

Sedlin (MIM 300202), Cathepsin K (MIM 601105), MMP2 (MIM 120360), lizozomal asid hidrolazlar, EXT1 (MIM 608177), EXT2 (MIM 608210), SH3BP2 (MIM 602104)

FGFR1 (MIM 136350), FGFR2 (MIM 176943), FGFR3 (MIM 134934), ROR2 (MIM 602337), GNAS1 (MIM 139320), FGF23 (MIM 605380), CASR (MIM 601199)

SOX9 (MIM 608160), TRPS1 (MIM 604386), CBFA1 (MIM 600211), LMX1B (MIM 602575), SHOX (MIM 312865), EVC (MIM 604831), DLX3 (MIM 600525), HOXD13 (MIM 142989), MSX2 (MIM 123101), ALX4 (MIM 605420), TBX3 (MIM 601621), NEMO (MIM 300248)

ADA (MIM 608958), RMRP (MIM 157660)

Filamin A (MIM 300017), Filamin B (MIM 603381) 
Tablo 13. İskelet displazisine neden olan bazı gen mutasyonları, kodladıkları proteinler ve neden oldukları fenotip

\begin{tabular}{|c|c|c|c|}
\hline Gen/Lokus & Protein & Protein Fonksiyonu & Klinik Fenotip \\
\hline COL2A1 & $\begin{array}{l}\text { Tip II kollajen alpha } 1 \\
\text { zinciri }\end{array}$ & Kıkırdak matriks proteini & $\begin{array}{l}\text { Akondrogenezis } 2 \\
\text { Hipokondrogenezis } \\
\text { SED konjenita } \\
\text { Kniest displazi } \\
\text { Geç başlangıçlı SED } \\
\text { Stickler displazi }\end{array}$ \\
\hline COL9A2 & $\begin{array}{l}\text { Tip IX kollajen alpha } 2 \\
\text { zinciri }\end{array}$ & Kıkırdak matriks proteini & Multipl epifizyel displazi \\
\hline COL9A3 & $\begin{array}{l}\text { Tip IX kollajen alpha } 3 \\
\text { zinciri }\end{array}$ & Kıkırdak matriks proteini & Multipl epifizyel displazi \\
\hline COL10A1 & $\begin{array}{l}\text { Tip X kollajen alpha } 1 \\
\text { zinciri }\end{array}$ & Hipertrofik kıkırdak matriks proteini & Metafizyel displazi, Schmid tipi \\
\hline COL11A1 & $\begin{array}{l}\text { Tip XI kollajen alpha } 1 \\
\text { zinciri }\end{array}$ & Kıkırdak matriks proteini & Stickler benzeri displazi \\
\hline COL11A2 & $\begin{array}{l}\text { Tip XI kollajen alpha } 2 \\
\text { zinciri }\end{array}$ & Kıkırdak matriks proteini & Stickler benzeri displazi \\
\hline ACG1 & Aggrecan & Kıkırdak matriks proteini & $\begin{array}{l}\text { SED Kimberley } \\
\text { SEMD Aggrecan tipi }\end{array}$ \\
\hline COMP & $\begin{array}{l}\text { Kıkırdak oligomerik } \\
\text { matriks proteini }\end{array}$ & Kıkırdak matriks proteini & $\begin{array}{l}\text { Psödoakondroplazi } \\
\text { Multipl epifizyel displazi }\end{array}$ \\
\hline MATN3 & Matrillin 3 & Kıkırdak matriks proteini & Multipl epifizyel displazi \\
\hline FGFR3 & FGF reseptör 3 & FGF'ler için tirozin kinaz reseptörü & $\begin{array}{l}\text { Akondroplazi } \\
\text { Hipokondroplazi } \\
\text { Tanatoforik displazi 1, Tanatoforik displazi } 2\end{array}$ \\
\hline PTHR1 & PTHrP reseptör & PTH ve PTHrP için G protein coupled reseptör & Metafizyel displazi Jansen tipi \\
\hline DTDST & DTD sülfat transporter & Transmembran sülfat transporter & $\begin{array}{l}\text { Akondrogenezis } 1 \mathrm{~b} \\
\text { Atelosteogenezis } 2 \\
\text { Diastrofik displazi }\end{array}$ \\
\hline PAPSS2 & PAPS-Synthetase 2 & phosphoadenosine-phosphosulfate synthetase & $\begin{array}{l}\text { Brakiyolmia resesif tip } \\
\text { SEMD, PAPSS2 tipi }\end{array}$ \\
\hline TRPV4 & $\begin{array}{l}\text { Kalsiyum geçirgen } \\
\text { TRP iyon kanalı }\end{array}$ & Transmembran kanal proteini & $\begin{array}{l}\text { Brakiyolmia } \\
\text { Spondilometafizyel displazi - Kozlowski tipi } \\
\text { Metatrofik displazi }\end{array}$ \\
\hline SOX9 & SRY box 9 & Transkripsiyon faktörü & Kampomelik displazi \\
\hline RMPR & $\begin{array}{l}\text { Mitokondriyal } \\
\text { RNA-processing } \\
\text { endoribonukleaz }\end{array}$ & $R N A$-processing enzim & $\begin{array}{l}\text { Anauxetic dysplasia } \\
\text { Kıkırdak saç hipoplazisi } \\
\text { Hipotrikozis olmadan kıkırdak saç hipoplazisi }\end{array}$ \\
\hline RUNX2 & $\begin{array}{l}\text { Runt-iliş̧kili } \\
\text { transkripsiyon faktörü }\end{array}$ & Transkripsiyon faktörü & Kleidokraniyal displazi \\
\hline
\end{tabular}


Tablo 14. Bazı transkripsiyon faktörlerinin neden olduğu iskelet displazileri ve dizostozisler

\begin{tabular}{|c|c|c|c|c|}
\hline & Hastalık adı & $\begin{array}{l}\text { Kalıtım } \\
\text { paterni }\end{array}$ & Gen & Protein \\
\hline \multirow{3}{*}{$\begin{array}{l}\text { İskelet } \\
\text { displazisi }\end{array}$} & Kampomelik displazi & OD & SOX9 & SOX9 transkripsiyon faktörü \\
\hline & Trikorinofalangeal sendrom & OD & TRPS1 & TRPS1 transkripsiyon faktörü \\
\hline & Diskondroosteozis & XD & SHOX & SHOX transkripsiyon faktörü \\
\hline \multirow[t]{10}{*}{ Dizostozis } & Al-Awadi/Raas-Rothschild syndrome & OR & WNT7A & Winless-type MMTV integration site family, member $7 A$ \\
\hline & Ulnar-mammary syndrome & OD & TBX3 & T-box 3 transkripsiyon faktörü \\
\hline & Holt-Oram syndrome & OD & TBX5 & T-box 5 transkripsiyon faktörü \\
\hline & Cousin syndrome & OR & TBX15 & T-box 15 transkripsiyon faktörü \\
\hline & Hand-foot-genital syndrome & OD & HOXA13 & Homeobox-containing A13 transkripsiyon faktörü \\
\hline & Greig polisindaktili & OD & Gli3 & GLI-Kruppel family member 3 transkripsiyon faktörü \\
\hline & Brakidaktili A & OD & $\mathrm{IHH}$ & Indian hedgehog \\
\hline & Brakidaktili B & OD & ROR2 & Receptor tyrosine kinase-like orphan receptor 2 \\
\hline & Brakidaktili C & OD & GDF5 & Growth and differentiation factor 5 \\
\hline & Cenani-Lenz syndrome & OR & LRP4 & Low density lipoprotein-receptor related protein 4 \\
\hline
\end{tabular}

\section{KAYNAKLAR}

1. Bonafe L, Cormier-Daire V, Hall C, Lachman R, Mortier G, Mundlos S, Nishimura G, Sangiorgi L, Savarirayan R, Sillence D, Spranger J, Superti-Furga A, Warman M, Unger $\mathrm{S}$. Nosology and classification of genetic skeletal disorders: 2015 revision. Am J Med Genet A 2015;167A(12):2869-92. Crossref

2. Orioli IM, Castilla EE, Barbosa-Neto JG. The birth prevalance rates for the skeletal dysplasias. J Med Genet 1986;23(4):328-32.

3. Kurt-Sukur ED, Simsek-Kiper PO, Utine GE, Boduroglu $\mathrm{K}$, Alanay Y. Experience of a skeletal dysplasia registry in Turkey: a five-years retrospective analysis. Am J Med Genet A 2015;167A(9):2065-74. Crossref

4. Michigami T. Current understanding on the molecular basis of chondrogenesis. Clin Pediatr Endocrinol 2014;23(1):1-8. Crossref

5. Karsenty G. Transcriptional control of skeletogenesis, Annu Rev Genomics Hum Genet 2008;9:183-96. Crossref

6. Kuivaniemi $\mathrm{H}$, Tromp G, Prockop DJ. Mutations in fibrillar collagens (types I, II, III, and XI), fibril-associated collagen (type IX), and network-forming collagen (type $X$ ) cause a spectrum of diseases of bone, cartilage, and blood vessels. Hum Mutat 1997;9(4):300-15.

7. Eyre DR. Collagens and cartilage matrix homeostasis. Clin Orthop Relat Res 2004;(427 Suppl):S118-22.

8. Spranger JW, Brill P, Superti-Furga A, Unger S, Nishimura $\mathrm{G}$, editors. Bone dysplasias. An Atlas of Genetic Disorders of Skeletal Development, 3rd ed. Oxford: Oxford University Press; 2012. p.10-8.

9. Krakow D. Skeletal dysplasias. Clin Perinatol 2015;42(2):30119. Crossref

10. Wells AL, Wells TR, Landing BH, Cruz B, Galvis DA. Short trachea, a hazard in tracheal intubation of neonates and infants: syndromal associations. Anesthesiology 1989;71(3):367-73.
11. Krakow D, Lachman RS, Rimoin DL. Guidelines for the prenatal diagnosis of fetal skeletal dysplasias. Genet Med 2009;11(2):127-33. Crossref

12. Superti-Furga A, Bonafé L, Rimoin DL. Molecularpathogenetic classification of genetic disorders of the skeleton. Am J Med Genet 2001;106(4):282-93.

13. Rimoin DL, Cohn D, Krakow D, Wilcox W, Lachman RS, Alanay Y. The skeletal dysplasias: clinical-molecular correlations. Ann N Y Acad Sci 2007;1117:302-9.

14. Krakow D, Rimoin DL. The sekletal dysplasias. Genet Med 2010;12(6):327-41. Crossref

15. Hall JG, Froster-Iskenius UG, Allanson JE. Handbook of Normal Physical Measurements. Oxford, UK: Oxford University Press; 1989.

16. Mortier GR. The diagnosis of skeletal dysplasias: a multidisciplinary approach. Eur J Radiol 2001;40(3):161-7.

17. Lachman RS. Taybi and Lachman's Radiology of syndromes metabolic disorders and skeletal dysplasias, 5th ed. Philadelphia, PA, USA: Mosby Elsevier Co.; 2007.

18. Rimoin DL, Sillence DO. Chondro-osseous morphology and biochemistry in the skeletal dysplasias, Birth Defects Orig Artic Ser 1981;17(1):249-65.

19. Auer-Grumbach $M$, Olschewski A, Papić L, Kremer $H$, McEntagart ME, Uhrig S, Fischer C, Fröhlich E, Bálint Z, Tang B, Strohmaier H, Lochmüller $H$, Schlotter-Weigel B, Senderek J, Krebs A, Dick KJ, Petty R, Longman C, Anderson NE, Padberg GW, Schelhaas HJ, van RavenswaaijArts CM, Pieber TR, Crosby AH, Guelly C. Alterations in the ankyrin domain of TRPV4 cause congenital distal SMA, scapuloperoneal SMA and HMSN2C. Nat Genet 2010;42(2):160-4. Crossref

20. Geister KA, Camper SA. Advances in Skeletal Dysplasia Genetics. Annu Rev Genomics Hum Genet 2015;16:199-227. Crossref 
21. Laine CM, Joeng KS, Campeau PM, Kiviranta R, Tarkkonen K, Grover M, Lu JT, Pekkinen M, Wessman M, Heino TJ, Nieminen-Pihala V, Aronen M, Laine T, Kröger H, Cole WG, Lehesjoki AE, Nevarez L, Krakow D, Curry CJ, Cohn DH, Gibbs RA, Lee BH, Mäkitie O. WNT1 mutations in earlyonset osteoporosis and osteogenesis imperfecta. N Engl J Med 2013;368(19):1809-16. Crossref

22. Cohn DH, Apone S, Eyre DR, Starman BJ, Andreassen $\mathrm{P}$, Charbonneau $\mathrm{H}$, Nicholls AC, Pope FM, Byers $\mathrm{PH}$. Substitution of cysteine for glycine within the carboxylterminal telopeptide of the alpha 1 chain of type I collagen produces mild osteogenesis imperfecta. J Biol Chem 1988;263(29):14605-7.

23. Marini JC, Forlino A, Cabral WA, Barnes AM, San Antonio JD, Milgrom S, Hyland JC, Körkkö J, Prockop DJ, De Paepe A, Coucke P, Symoens S, Glorieux FH, Roughley PJ, Lund AM, Kuurila-Svahn K, Hartikka H, Cohn DH, Krakow D, Mottes M, Schwarze U, Chen D, Yang K, Kuslich C, Troendle J, Dalgleish R, Byers $\mathrm{PH}$. Consortium for osteogenesis imperfecta mutations in the helical domain of type I collagen: regions rich in lethal mutations align with collagen binding sites for integrins and proteoglycans. Hum Mutat 2007;28(3):209-21.

24. Byers PH, Pyott SM. Recessively inherited forms of osteogenesis imperfecta. Annu Rev Genet 2012;46:475-97. Crossref
25. Klag KA, Horton WA. Advances in treatment of achondroplasia and osteoarthritis. Hum Mol Genet 2016;25(R1):R2-8. Crossref

26. Muenzer J. Early initiation of enzyme replacement therapy for the mucopolysaccharidoses. Mol Genet Metab 2014;111(2):63-72. Crossref

27. Allen DB, Cuttler L. Short stature in childhood -challenges and choices. N Engl J Med 2013;368(13):1220-8. Crossref

28. Krakow D, Williams J 3rd, Poehl M, Rimoin DL, Platt LD. Use of three-dimensional ultrasound imaging in the diagnosis of prenatal-onset skeletal dysplasias. Ultrasound Obstet Gynecol 2003;21(5):467-72.

29. Fan HC, Blumenfeld YJ, Chitkara U, Hudgins L, Quake SR. Noninvasive diagnosis of fetal aneuploidy by shotgun sequencing DNA from maternal blood. Proc Natl Acad Sci U S A 2008;105(42):16266-71. Crossref

30. Saito $H$, Sekizawa A, Morimoto T, Suzuki M, Yanaihara T. Prenatal DNA diagnosis of a single-gene disorder from maternal plasma. Lancet 2000;356(9236):1170. 